\title{
Electron microscopic visualization of membrane-mediated uptake and translocation of estrogen-BSA:colloidal gold by Hep G2 cells
}

\author{
R K Moats II and V D Ramirez \\ Department of Molecular and Integrative Physiology, University of Illinois at Urbana-Champaign, Urbana, Illinois 61801, USA \\ (Requests for offprints should be addressed to V D Ramirez; Email: vdramire@staff.uiuc.edu)
}

\begin{abstract}
Previously, we have identified a membrane-mediated uptake and translocation of 1,3,5(10)-estratrien-3, 17 $\beta$ diol 6-(O-carboxymethyl)oxime: ${ }^{125}$ I-labeled BSA $\left(\right.$ E6 $\left.{ }^{125} \mathrm{I}-\mathrm{BSA}\right)$ in vivo in immature female rat liver from the plasma membrane (P3 fraction) to the mitochondria and/or lysosomes (P2 fraction). To further investigate this unique effect, current experiments have involved the use of 1,3,5(10)-estratrien-3, 17 $\beta$-diol 17-hemisuccinate: ${ }^{125} \mathrm{I}$ BSA (E1 $\left.{ }^{125} \mathrm{I}-\mathrm{BSA}\right)$ to demonstrate the presence of binding sites and translocation of the ligand in human hepatoblastoma (Hep G2) cells. In addition, an estrogenBSA:colloidal gold conjugate, E17 BSA:Au, was used to directly visualize this uptake in Hep G2 cells. Hep G2 cells displayed high-affinity, stereospecific binding of E1 ${ }^{125} \mathrm{I}-$ BSA. This same ligand was also translocated from the P3 fraction to the $\mathrm{P} 2$ fraction. In contrast, ${ }^{125} \mathrm{I}$-BSA was minimally removed from the culture medium. Electron micrographs of Hep G2 cells labeled with E17 BSA:Au demonstrated uptake of this ligand by clathrin-coated pits, indicative of receptor-mediated endocytosis. Furthermore, this ligand was also found in larger vesicles and multi-
\end{abstract}

vesicular bodies, suggesting the involvement of the compartment of uncoupling of receptor and ligand (CURL), but never in the nucleus. As early as $30 \mathrm{~min}$ postexposure, the ligand could be viewed in organelles, many of which had vesiculated interiors, resembling rounded, vesiculated mitochondria. Labeled BSA was detected mainly in the extracellular compartment, with few multivesicular bodies containing the labeled BSA. The translocation of E17 BSA:Au was virtually eliminated by $100 \mathrm{nM}$ unlabeled E17 BSA or free $17 \beta$-estradiol, but not $17 \alpha-E 6$ BSA, $17 \alpha$-estradiol or P6 BSA, and also by exposure of the cells to reduced temperature. These experiments are the first to visually demonstrate membrane binding and specific uptake of an estrogencontaining ligand while allowing the intracellular structures responsible to be seen. Furthermore, they identify a potentially new pathway of receptor-mediated endocytosis; namely, the shuttling of estrogens to the mitochondria, in addition to the classical lysosomal pathway.

Journal of Endocrinology (2000) 166, 631-647

\section{Introduction}

Estrogen and other steroid hormones are well-known lipophilic molecules that interact with intracellular transcription-factor receptors. These receptors migrate, when necessary, from the cytosol to the nucleus and enhance or repress the transcription of responsive genes a process that takes minutes to hours to complete (Katzenellenbogen et al. 1996).

Also evident among the responses of target cells to steroid hormones are rapid, transient responses, which presumably do not involve the classical intracellular receptor signal transduction system (Ramirez 1996, Wehling 1997). These so-called 'non-genomic' responses to steroid hormones may involve either soluble cytosolic factors other than (Joe et al. 1997), or including, the intracellular receptor (Migliaccio et al. 1996) or some unidentified membrane receptor or binding protein for the steroid (Ramirez et al. 1996).

Evidence for membrane receptors or binding proteins for estrogen has recently increased; this is primarily due to the development of impeded ligands which cannot passively penetrate the plasmalemma either because of a large protein moiety (Zheng et al. 1996) or because of anchorage to a fixed support (Pietras \& Szego 1979). Many investigators have shown that these ligands substitute very well for free estrogen and mimic its physiological effects (Zheng et al. 1996, Audy et al. 1996, Prevot et al. 1999); any large protein component, such as BSA, can be easily labeled without interfering with the structure of the conjugated estrogen (Zheng et al. 1996). The presence of BSA, in particular, does not appear to cause the activity of these ligands. For example, a ligand containing the less active form of estradiol, $17 \alpha$-estradiol, conjugated to BSA is a 
poor inhibitor of $17 \beta$-estradiol-BSA (E17 BSA) binding to liver plasmalemmal/microsomal fractions (Moats \& Ramirez 1998). The E17 BSA conjugate is also a very good competitor $\left(K_{\mathrm{i}}=0.024 \mathrm{nM}\right)$ in radioreceptor assays using $\left[{ }^{3} \mathrm{H}\right]$ estradiol binding to the uterine nuclear receptor (Zheng \& Ramirez 1999a).

Recently, our laboratory has uncovered a presumed membrane-mediated uptake of an estrogen-containing ligand, 17ß-estradiol 6-(O-carboxymethyl) oxime: ${ }^{125} \mathrm{I}-$ BSA (E6 $\left.{ }^{125} \mathrm{I}-\mathrm{BSA}\right)$ by immature and ovariectomized female rat livers (Moats \& Ramirez 1998). Differential centrifugation of labeled liver samples uncovered the rapid translocation of the ligand to the mitochondrial and/or lysosomal compartment of the cells rather than to the nucleus. Prior to this finding, members of our group had reported that a component of the mitochondrial F-type ATPase, oligomycin sensitivity-conferring protein (OSCP), specifically bound not only E6 BSA, but also $\left[{ }^{3} \mathrm{H}\right]$ estradiol (Ramirez \& Zheng 1999, Zheng \& Ramirez 1999b). This translocation, then, may serve as a means by which specific cells can shuttle estrogen to the mitochondria to modify their functions (Troyan et al. 1997) in addition to the transcriptional activity of the hormone.

The goal of these experiments was to directly visualize, using electron microscopy, the uptake and translocation of an estrogen-containing ligand, $17 \beta$-estradiol 17hemisuccinate:BSA that had been adsorbed to colloidal gold (E17 BSA:Au). Confounding factors, such as dilution of the ligand in the blood and the potentially random binding of the ligand in the liver, can be avoided, as shown in this report, through the use of human hepatoblastoma (Hep G2) cells in culture instead of in vivo injections. Despite the lack of intracellular estrogen receptors in these cells (Enmark et al. 1997, Mattick et al. 1997), they have been shown to respond rapidly to estradiol, but not progesterone, with a 10-fold increase in inositol triphosphate (Marino et al. 1998), indicating a membrane-mediated effect of estrogen. In addition, specific membrane binding sites for the E17 BSA conjugate and its translocation to a mitochondrial/lysosomal fraction are shown.

\section{Materials and Methods}

\section{Cell culture}

A $75 \mathrm{~cm}^{2}$ starter flask of estrogen receptor $\alpha$-negative Hep G2 cells was the generous gift of Dr David Shapiro and Jurgen de Haan. This flask was subcultured 1:3-4 in high glucose, phenol red-free Dulbecco's modified Eagles' medium (DMEM; University of Illinois Cell Media Facility) which was supplemented with $10 \%$ fetal bovine serum (Sigma, St Louis, MO, USA) and 1\% penicillin/ streptomycin solution (Gibco-BRL, Gaithesburg, MD, USA). Under these conditions, these Hep G2 cells do not grow well at greater subculturing dilutions.
Briefly, the cells were removed from the flask, with a cell scraper, into a given amount of media and aspirated gently several times with a $10 \mathrm{ml}$ pipette. The suspended cells were then transferred to a $50 \mathrm{ml}$ conical centrifuge tube and aspirated twice by syringe through a 20 -gauge needle. Upon the second passage, the cells were transferred into new culture flasks and diluted with media. A single $75 \mathrm{~cm}^{2}$ flask will yield three $75 \mathrm{~cm}^{2}$ flasks for continued culture, four or five $25 \mathrm{~cm}^{2}$ flasks for experiments, or three 6-well culture dishes for experiments. All subcultures were grown at $37^{\circ} \mathrm{C}$ in $5 \% \mathrm{CO}_{2}$ for 1 week, with media changes every 2 or 3 days, before being used for experiments or subculturing.

\section{Isolation of membrane fractions}

Medium was decanted from five to seven $75 \mathrm{~cm}^{2}$ culture flasks, 1 week post-subculture, and replaced with $2 \mathrm{ml}$ HBBA $(0 \cdot 5 \mathrm{mM} \mathrm{CaCl}, 0 \cdot 25 \mathrm{mM}$ sucrose, $5 \mathrm{mM}$ Tris in distilled water; $\mathrm{pH} 7 \cdot 4$ at $4{ }^{\circ} \mathrm{C}$ ). The cells were removed from the flask into the buffer, with a cell scraper, and aspirated with a Pasteur pipette into a small glass homogenizer with a tight-fitting Teflon pestle. The cells were kept on ice and homogenized with 15 strokes by hand, pooled, and poured into centrifuge tubes.

To isolate the P1 fraction, cell nuclei and debris, the tubes were centrifuged for $10 \mathrm{~min}$ at $600 \times \mathbf{g}$ and $4{ }^{\circ} \mathrm{C}$. The resulting supernatant was centrifuged a second time for $5 \mathrm{~min}$ at $15000 \times \mathbf{g}$ and $4{ }^{\circ} \mathrm{C}$ to produce the P2 fraction (mitochondria and lysosomes). Finally, the remaining supernatant was ultracentrifuged for $1 \mathrm{~h}$ at $125000 \times \mathbf{g}$ and $4{ }^{\circ} \mathrm{C}$ to isolate the P3 fraction (plasmalemmal and microsomal membranes). All pellet fractions were resuspended in 100-300 $\mu \mathrm{l} \mathrm{HBBA}$, depending on the pellet volume, and stored at $-20{ }^{\circ} \mathrm{C}$ until use. The protein concentrations of these resuspended fractions were determined by the Bradford method (Bradford 1976).

\section{Binding assay of Hep G2 P3 fractions}

The reaction buffer for competitive binding assays (BB) was $0.08 \%(\mathrm{w} / \mathrm{v})$ BSA (Sigma; St Louis, MO) in P2-Tris (P2-Tris: $50 \mathrm{mM}$ Tris- $\mathrm{HCl}, 120 \mathrm{mM} \mathrm{NaCl}, 5 \mathrm{mM} \mathrm{KCl}$, $1 \mathrm{mM} \mathrm{MgSO}_{4}, 1 \mathrm{mM} \mathrm{CaCl}_{2}$, and $10 \%$ glycerol, $\mathrm{pH} 7 \cdot 4$ at $4{ }^{\circ} \mathrm{C}$ ). $17 \beta$-estradiol 17-hemisuccinate:BSA (E17 BSA, $32 \mathrm{~mol}$ steroid/mol BSA) was purchased (Steraloids, Wilton, NH, USA) and radioiodinated (Amersham, Arlington Heights, IL, USA) by a method published previously (Moats \& Ramirez 1998).

A sampling manifold assembly (Model 1225; Millipore, Bedford, MA, USA) containing 12 Whatman GF/C filters was used to separate free ligand from bound ligand; the filters were pretreated with $300 \mu \mathrm{BB}$. The whole system was then placed in a cold room $\left(4^{\circ} \mathrm{C}\right)$ to come to reaction temperature while the binding assay took place. 


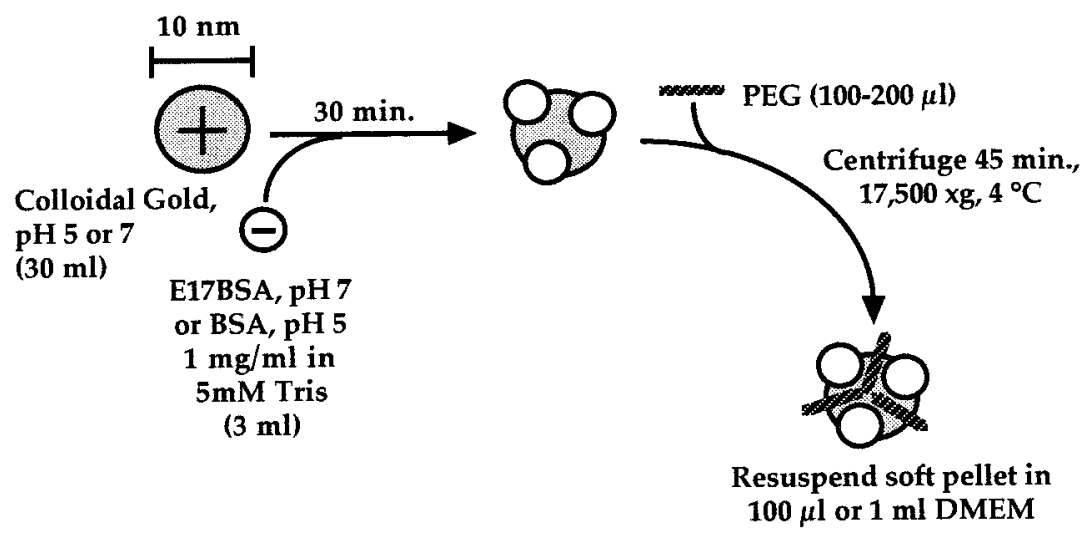

Figure 1 A diagram of the conjugation of E17 BSA or BSA to $10 \mathrm{~nm}$ colloidal gold. PEG, polyethylene glycol compound. For details, see Materials and Methods.

Competitive binding assay tubes contained 22500 c.p.m. radioactive ligand $(0.5-1 \mathrm{nM}), 17 \beta$-estradiol 17 hemisuccinate: ${ }^{125}$ I-BSA (E17 ${ }^{125} \mathrm{I}$-BSA), varying concentrations of competitor $(0 \cdot 05 \mathrm{nM}$ to $1 \mu \mathrm{M})$, if necessary, and BB. A final volume of $250 \mu \mathrm{l}$ was achieved by the addition of $0.5 \mu \mathrm{g}$ membrane protein in the form of diluted P3 pellet $(0.05 \mu \mathrm{g} / \mu \mathrm{l}$ in $\mathrm{BB})$, and the tubes were moved immediately to the cold room (where they were agitated for $30 \mathrm{~min}$ ). As the reaction time ended, a high vacuum was applied to the manifold and the reactions were terminated by the addition of $4-4.5 \mathrm{ml} \mathrm{BB}$ to the reaction tubes. The contents of each tube were rapidly poured through the corresponding opening in the manifold, the tube washed a second time with $\mathrm{BB}$, and the wash poured again through the corresponding opening. The radioactive filters from the manifold were removed and placed in small plastic culture tubes for gamma counting at $70 \%$ efficiency.

\section{Radioactive labeling of Hep G2 membrane fractions}

On the basis of previous results, it is clear that estrogencontaining protein ligands can be transported into the cell, presumably via a membrane-mediated mechanism. To investigate this mechanism further, intact Hep G2 cells in culture were incubated with E17 ${ }^{125}$ I-BSA or ${ }^{125}$ I-BSA for varying time periods and the labeled membranes were then isolated as described above.

The $2 \mathrm{ml}$ medium from a $25 \mathrm{~cm}^{2}$ culture flask were decanted and replaced with a similar amount of medium containing approximately $1 \times 10^{6}$ c.p.m. radioactive ligand (2-4 $\mathrm{nM}$; confirmed by gamma-counting a sample of medium). The flask was then incubated for 30,60 or $120 \mathrm{~min}$ on a rotating shaker at $37^{\circ} \mathrm{C}$. Often, several incubations were carried out simultaneously. The medium was sampled $(100 \mu \mathrm{l})$, carefully decanted and the cells rinsed with $2 \mathrm{ml}$ phosphate-buffered saline (PBS; pH 7·4 at $4{ }^{\circ} \mathrm{C}$ ). One hundred microliters of the rinse were sampled and the remaining rinse decanted and replaced with $2 \mathrm{ml} \mathrm{HBBA}$. The cells were then removed from the flask, with a cell scraper, into the HBBA, transferred to a $15 \mathrm{ml}$ conical centrifuge tube on ice and homogenized for differential centrifugation as described above. One hundred microliters of all supernatant fractions were reserved for gamma-counting. Pellet fractions were resuspended in $100 \mu \mathrm{l} \mathrm{HBBA}$, total volumes recorded, and the entire resuspended pellet gamma-counted. The resulting counts per minute (c.p.m.) were converted to fmol ligand bound, based on the specific activity of the ligand $(100-200 \mu \mathrm{Ci}$ / nmol). The protein concentration of each pellet was determined by using the Bradford assay (Bradford 1976) and the latter two values for each pellet were combined to determine fmol ligand/mg protein.

\section{Colloidal gold conjugation of E17 BSA or BSA}

Thirty milliliters of colloidal gold solution (average diameter $10.0 \mathrm{~nm}$; British Biocell International, Cardiff, UK) were brought to $\mathrm{pH} 7$ (for E17 BSA) or $\mathrm{pH} 5$ (for BSA) and filtered through a $0.45 \mu \mathrm{m}$ syringe filter. Three milligrams E17 BSA or BSA were dissolved in $3 \mathrm{ml}$ filtered $5 \mathrm{mM}$ Tris, sonicated briefly $(<10 \mathrm{~s})$ to ensure solubility, and brought to $\mathrm{pH} 8$ or $\mathrm{pH} 5$ respectively. The ligand solution was added dropwise with stirring to the gold colloid and the mixture gently stirred for $30 \mathrm{~min}$ at room temperature. At the end of the reaction period, 100-200 $\mu 1 \%$ polyethylene glycol compound (mol. wt 20000 , Sigma) and $100 \mu \mathrm{l}$ of $10 \% \mathrm{NaCl}$ in distilled water were added and the mixture stirred for an additional 1-2 min. The mixture was then divided evenly over six centrifuge tubes and centrifuged for $45 \mathrm{~min}$ at $17500 \times \mathbf{g}$ and $4{ }^{\circ} \mathrm{C}$. The resulting soft pellets of the ligand:gold conjugates were each resuspended under sterile conditions in $100 \mu \mathrm{l}$ or $1 \mathrm{ml}$ DMEM (see below) and all six suspensions were pooled (Fig. 1). The media suspensions of colloidal gold ligands were stored at $4{ }^{\circ} \mathrm{C}$ for no longer 


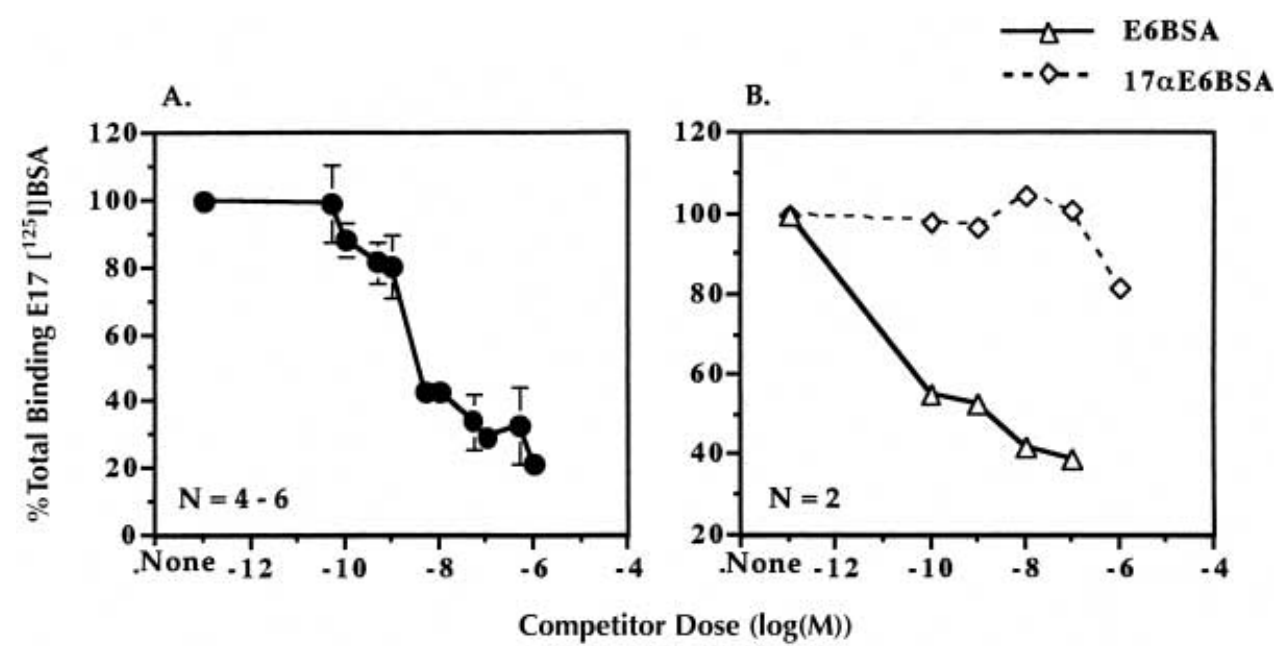

\begin{abstract}
Figure 2 Hep G2 P3 membrane fractions (0.5 $\mu$ g protein) were incubated with 22500 c.p.m. E1 $7^{125}$ I-BSA and various competitors $(0.5 \mathrm{nM}-1 \mu \mathrm{M})$ for $30 \mathrm{~min}$ at $4{ }^{\circ} \mathrm{C}$. Bound ligand and free ligand were separated by vacuum filtration through Whatman GF-C glass-fiber filters and the filters evaluated in a gamma-counter. The resulting data are presented as per cents of total binding (i.e. no competitor). (A) Homologous competition of E1 $7^{125}$ I-BSA binding to Hep G2 P3 fractions uncovered a single binding site with a $K_{d}$ value of $1.26 \mathrm{nM}$ and a $B_{\max }$ value of $68 \mathrm{fmol}$ ligand/mg protein. Means and S.E. values are shown. (B) Heterologous competition studies using a similar unlabeled ligand, E6 BSA, resulted in a $K_{\mathrm{i}}$ value near to, or better than, the homologous ligand. However, a $17 \alpha$-estradiol conjugate, $17 \alpha$-E6 BSA, was not effective as a competitor, even at $1 \mu \mathrm{M}$. Mean values are shown. These data indicate that plasmalemmal/microsomal membrane fractions from Hep G2 cells contain at least one binding site specific for the more biologically active form of estradiol.
\end{abstract}

than $24 \mathrm{~h}$ before use, but unused portions have remained in suspension for several weeks.

\section{Colloidal gold ligand labeling of Hep G2 cells}

The $1 \mathrm{ml}$ medium from one or more 6-well culture dishes of Hep G2 cells, 1 week post-subculture, was removed and replaced with $1 \mathrm{ml} /$ well DMEM containing E17 $\mathrm{BSA}: \mathrm{Au}$ or BSA:Au. Incubations then proceeded in the same manner as described above for E17 $7^{125}$ I-BSA, though the best results could be attained with $180 \mathrm{~min}$ of incubation. When competitors were included in the incubation conditions, cells were pre-incubated for $1 \mathrm{~h}$ in $1 \mathrm{ml} /$ well DMEM, with or without $100 \mathrm{nM}$ competitor, and the colloidal gold ligand in $100 \mu \mathrm{l}$ DMEM was added directly to these media. The incubation then proceeded for a further $180 \mathrm{~min}$. At the end of the incubation period, the medium was removed and the cells were fixed immediately in situ in Karnovsky's fixative in Sorensen's buffer (2\% paraformaldehyde, $2 \%$ glutaraldehyde in $0 \cdot 1 \mathrm{M}$ phosphate buffer, $\mathrm{pH} 7 \cdot 2$ ). The cells were scraped from the culture wells and placed in microcentrifuge tubes. The fixed cells stood at room temperature $1-3 \mathrm{~h}$ to ensure fixation and were then stored overnight at $4{ }^{\circ} \mathrm{C}$.

When the effect of temperature on the uptake of E17 BSA:Au was investigated, three of four 6-well culture plates were removed from the $37^{\circ} \mathrm{C}$ incubator and placed in a cold room (at approximately $4^{\circ} \mathrm{C}$ ) for $30 \mathrm{~min}$. After the $30 \mathrm{~min}$ preincubation, all four plates were treated with $1 \mathrm{ml} /$ well of either E17 BSA:Au or BSA:Au in DMEM, such that each plate had individual wells containing one of the two gold ligands. The three plates that had been preincubated at $4{ }^{\circ} \mathrm{C}$ were then returned to the cold room, while the fourth plate, which had remained at $37^{\circ} \mathrm{C}$, was returned to the incubator. All four plates were incubated with gentle agitation for $2 \mathrm{~h}$. Single plates were removed from the cold room after $30 \mathrm{~min}$ or $1 \mathrm{~h}$ of incubation and moved to $37{ }^{\circ} \mathrm{C}$ for the time remaining. A single plate remained in the cold room for the entire $2 \mathrm{~h}$. In a second series of experiments, 6-well plates containing Hep G2 cells were preincubated for $30 \mathrm{~min}$ at $4{ }^{\circ} \mathrm{C}$. The cells were then exposed to either E17 BSA:Au or BSA:Au for $15 \mathrm{~min}, 30 \mathrm{~min}$ or $45 \mathrm{~min}$ and then transferred to $37^{\circ} \mathrm{C}$ for $45 \mathrm{~min}, 30 \mathrm{~min}$ or $15 \mathrm{~min}$ respectively. At the end of the incubation period, the gold ligand was aspirated from the wells and the cells were fixed as described above.

\section{Determination of intracellular target organelle identity}

To identify the target organelles for E17 BSA:Au more conclusively, cells labeled with either E17 BSA:Au or $\mathrm{BSA}: \mathrm{Au}$ were fixed as above and then incubated for $30 \mathrm{~min}$ in a solution of $0.05 \%$ cytochrome $c$ (Sigma) and $15 \mathrm{mg} / \mathrm{ml}$ diaminobenzidine (DAB; Bio-Rad; Hercules, CA, USA) in $0 \cdot 1 \mathrm{M}$ PBS containing $0 \cdot 1 \%$ Triton X-100 (Bio-Rad) (Angermüller et al. 1998). This technique is 
Table 1 Uptake of E1 $17^{125}$ I-BSA or ${ }^{125}$ I-BSA by Hep G2 cell membrane pellet fractions over time. Different lower-case letters following E1 $17^{125}$ I-BSA values indicate significant differences according to Tukey post-hoc analysis $(P<0 \cdot 05$ or less)

\begin{tabular}{|c|c|c|c|c|c|c|c|}
\hline & \multirow{2}{*}{$\begin{array}{l}\text { Time } \\
(\min )\end{array}$} & \multicolumn{6}{|c|}{$\begin{array}{l}\text { Uptake } \\
\text { (fmol ligand/mg protein ( } \pm \text { S.E.M. }) \text { ) }\end{array}$} \\
\hline & & $\mathrm{P} 1$ & Change $^{1}(\%)$ & $\mathrm{P} 2$ & Change $^{1}(\%)$ & P3 & Change $^{1}(\%)$ \\
\hline \multicolumn{8}{|l|}{ Ligand } \\
\hline \multirow[t]{3}{*}{ E1 $17^{125}$ I-BSA } & 30 & $118 \cdot 6 \pm 43 a$ & 100 & $108 \cdot 8 \pm 28 a$ & 100 & $85 \cdot 5 \pm 20 b$ & 100 \\
\hline & 60 & $93 \cdot 8 \pm 31 \mathrm{a}$ & $79 \cdot 1$ & $110 \cdot 6 \pm 25 a$ & $101 \cdot 6$ & $63 \cdot 1 \pm 8 c$ & $73 \cdot 8$ \\
\hline & 120 & $118 \cdot 3 \pm 12 \mathrm{a}$ & $99 \cdot 7$ & $138 \cdot 1 \pm 13 \mathrm{a}$ & $126 \cdot 9$ & $53 \cdot 8 \pm 6 c$ & $62 \cdot 9$ \\
\hline \multirow[t]{3}{*}{${ }^{125}$ I-BSA } & 30 & $2 \cdot 1 \pm 0 \cdot 1$ & & $1 \cdot 5 \pm 0 \cdot 2$ & & $1 \cdot 5 \pm 0 \cdot 4$ & \\
\hline & 60 & $1 \cdot 8 \pm 0 \cdot 3$ & & $2 \cdot 0 \pm 0 \cdot 5$ & & $1 \cdot 2 \pm 0 \cdot 5$ & \\
\hline & 120 & $3 \cdot 0 \pm 0 \cdot 3$ & & $2 \cdot 3 \pm 0 \cdot 3$ & & $1 \cdot 4 \pm 0 \cdot 3$ & \\
\hline
\end{tabular}

${ }^{1}$ Relative to values at $30 \mathrm{~min}$.

effective at labeling mitochondria, increasing their visibility and facilitating identification. Following this incubation, the cells were rinsed three times with $0 \cdot 1 \mathrm{M}$ PBS, re-exposed to Karnovsky's fixative, and then removed from the culture dish and stored as above.

\section{Electron microscopy and gold-particle quantification}

Cells labeled with E17 BSA:Au and fixed in Karnovsky's fixative were processed for electron microscopy at the Center for Microscopy and Imaging, University of Illinois at Urbana-Champaign. Briefly, samples were fixed at $44{ }^{\circ} \mathrm{C}$ in a microwave oven $(8 \mathrm{~s}$ on, $20 \mathrm{~s}$ off, $8 \mathrm{~s}$ on, repeated four times), post-fixed with potassium cyanide and sequentially dehydrated in 25-100\% ethanol, 50\% acetonitrile and $100 \%$ acetonitrile. In previous trials, the colloidal gold ligand was not detected in liver samples treated with uranyl acetate (UA), therefore, UA staining was eliminated from the current protocol. The samples were then embedded in Lx-112 epoxy, and the epoxy polymerized for 2 days at $70{ }^{\circ} \mathrm{C}$. The resulting blocks were trimmed and sectioned at $50-70 \mathrm{~nm}$ and the sections mounted on copper grids. To improve contrast, the grids with sections could be briefly incubated in a mixture of lead salts and washed with distilled water before being viewed. Observations of the sections were made using an electron microscope with an accelerating voltage of 75 keV (H-600; Hitachi, Tokyo, Japan).

Thin sections of cells from the study of temperature effects on the uptake and translocation of E17 BSA:Au or $\mathrm{BSA} \mathrm{Au}$ (see above) were examined for the presence of intracellular gold particles; the intracellular particles were counted on the basis of their association with one of nine cellular compartments. Briefly, a copper grid containing one or more sections was placed into the electron microscope and the section was scanned at low power $(8000 \times)$ for representative cells (the gold particles are not readily apparent at this magnification). When a cell with acceptable morphology was found (i.e. a cell displaying a prominent nucleus and intact organelles), the magnifi-

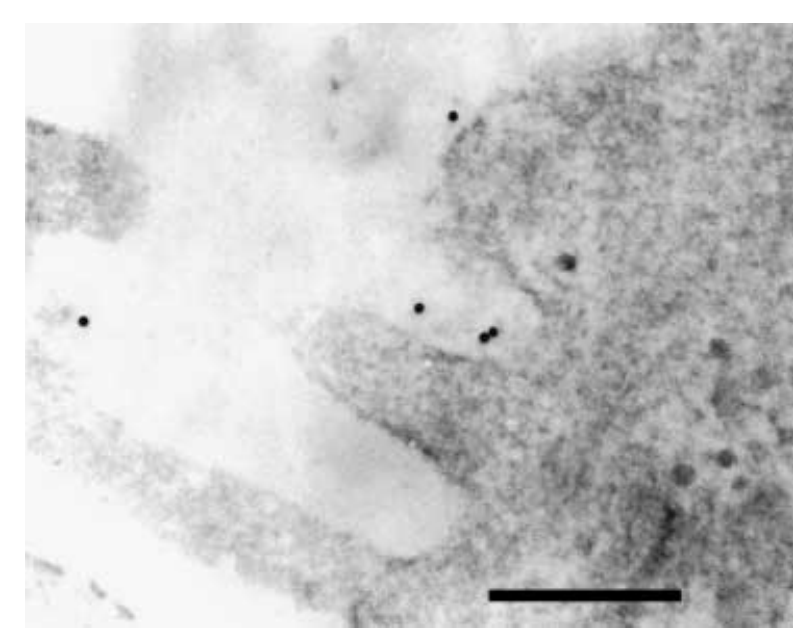

Figure 3 Hep G2 cells in culture were incubated for $15 \mathrm{~min}$ at $37^{\circ} \mathrm{C}$ in $1 \mathrm{ml} \mathrm{E} 17 \mathrm{BSA}: \mathrm{Au}$ in DMEM (approximately $10 \mathrm{nM}$ of the complex), fixed and subjected to electron microscopy (see Materials and Methods). The large protein component of the ligand (BSA) and the gold colloid prevent the passive diffusion of the ligand and allow it to bind to areas of microvilli on the cell surface. Magnification $=120000 \times$. Scale bar $=0.167 \mu \mathrm{m}$.

cation was increased to $20000 \times$ and the cell was scanned carefully for gold particles. The intracellular particles found in such a cell were counted according to their association with nine subcellular compartments, and the process was repeated for a total of five cells per experimental condition. When possible, only cells in the same grid square were analysed (to avoid duplicate particle counts).

\section{Statistical analysis}

Data from binding assays using Hep G2 P3 fractions were analysed by the LIGAND program (Munson \& Robard 1980) to determine $K_{\mathrm{d}}$ and $B_{\max }$ values. Potential outliers in the E1 $7^{125}$ I-BSA uptake data (fmol ligand/mg protein) were determined using the Q-test; the remaining values were analysed by two-way ANOVA followed by the Tukey 

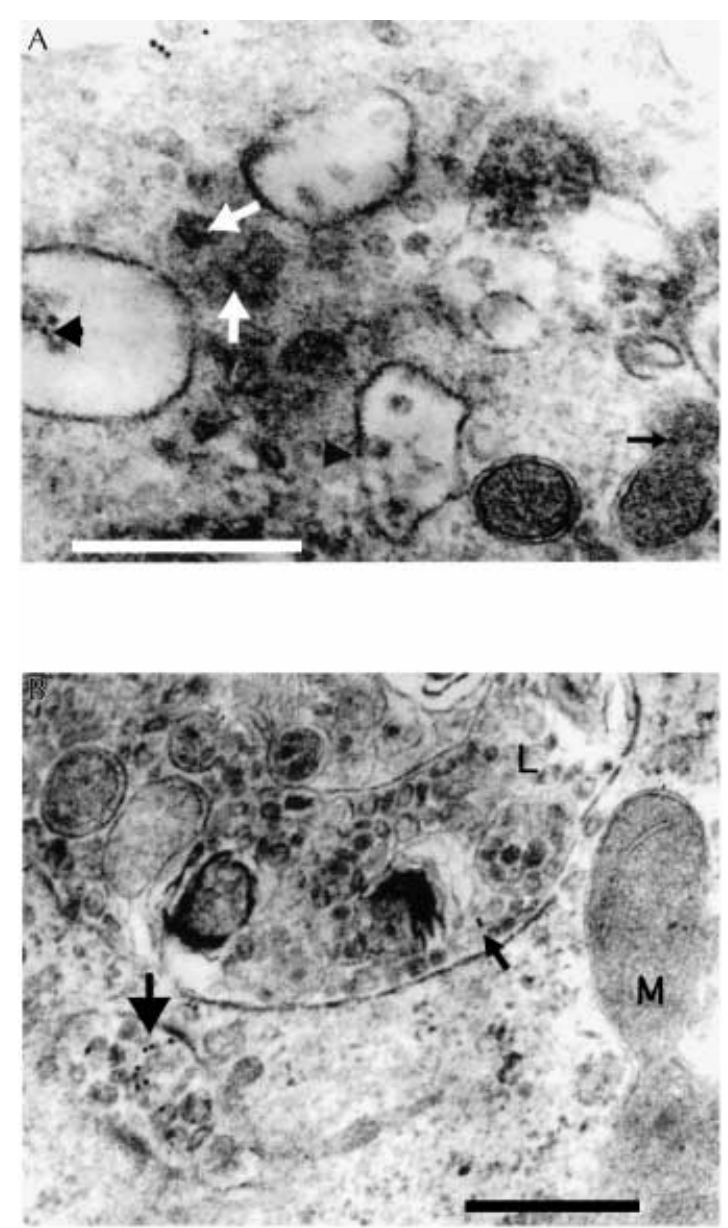

Figure 4 (A, B) Hep G2 cells in culture were incubated with E17 BSA:Au and subjected to electron microscopy as described in the Materials and Methods. After $3 \mathrm{~h}$ incubation, the ligand could be seen in several intracellular structures, suggesting receptormediated endocytosis. (A) Note the presence of ligand in small uncoated vesicles (white arrows), MVBs (arrowheads) and organelles displaying double membranes, resembling mitochondria (small arrows). Magnification $=40000 \times$. Scale bar $=0.5 \mu \mathrm{m}$. (B) The membrane-mediated uptake of E17 BSA:Au by Hep G2 cells resulted primarily in the transport of the ligand to organelles similar to MVBs (large arrow) rather than to the secondary lysosomes (small arrows). L, lysosome; $M$, mitochondrion. Magnification $=40000 \times$. Scale bar $=0.5 \mu \mathrm{m}$.

post-hoc multiple comparison test. Differences in intracellular gold-particle numbers and distribution were analysed by one- and two-way ANOVA followed by Tukey multiple comparison tests. In all cases, $P \leq 0.05$ was considered significant.

\section{Results}

Isolated plasmalemmal and microsomal membranes (P3 fractions) from Hep G2 human hepatoblastoma cells displayed high-affinity/high-capacity binding of E1 $17^{125} \mathrm{I}-$ BSA, which could be inhibited by both $17 \beta-E 17$ BSA and a related ligand, 17 $\beta$-E6 BSA (Fig. 2A and B). However, this form of E6 BSA, which contains 17 $\alpha$-estradiol $(17 \alpha-E 6$ BSA), was a poor competitor even at $1 \mu \mathrm{M}$ (Fig. $2 \mathrm{~B})$, suggesting that the observed binding of $\mathrm{E} 17^{125} \mathrm{I}-\mathrm{BSA}$ was due to the presence of the more biologically active form of estradiol. The $K_{\mathrm{d}}$ of this site for $17 \beta-\mathrm{E} 17 \mathrm{BSA}$ was $1.26 \mathrm{nM}$ and the $B_{\max }$ was $68 \mathrm{pmol} / \mathrm{mg}$ protein. The $K_{\mathrm{i}}$ for $17 \beta-E 6$ BSA was slightly less than the $K_{\mathrm{d}}$ for E17 BSA (see Fig. 2B). Unlike the P3 fraction from ovariectomized rat liver, in which two binding sites were evident (Moats \& Ramirez 1998), only one binding site was detected in P3 fractions from Hep G2 cells.

Hep G2 cells rapidly remove E1 $17^{125}$ I-BSA from the culture medium, an effect that seems largely dependent on the presence of estrogen conjugated to the ligand (Table 1). Initially (at $30 \mathrm{~min}$ post-exposure), the radioactivity detected in the three fractions of cells incubated with E1 $7^{125}$ I-BSA was not significantly different, though it was over 50 times greater than the radioactivity detected in fractions of cells incubated with ${ }^{125}$ I-BSA (Table 1). By $60 \mathrm{~min}$, the radioactivity in the P3 fraction was significantly lower than that of the P2 and P1 fractions. By $120 \mathrm{~min}$, a decrease of nearly $40 \%$ was observed in the P3 fraction, with a concomittant $27 \%$ (though not significant) increase in the P2 fraction and no change in the P1 fraction. These results indicate the importance of the estrogen component of the complex for the translocation phenomenon. Moreover, ${ }^{125}$ I-BSA was minimally removed from the culture medium by the cells (Table 1).

To clarify the membrane-mediated uptake and translocation of estrogen conjugate ligands, a colloidal gold conjugate of E17 BSA (E17 BSA:Au) was incubated with Hep G2 cells in culture. Electron microscopy could then be used to clearly define the uptake event as membranemediated and visually identify the exact intracellular target(s) of the ligand. The selectivity of this ligand was confirmed in ligand blots of affinity-purified, digitonin-solubilized liver P3 fractions. E17 BSA:Au could identify proteins of similar molecular weight as proteins that specifically bound E17 $7^{125}$ I-BSA (not shown).

The uptake of E17 BSA:Au from the medium by Hep G2 cells was not as rapid as the uptake of E6 ${ }^{125}$ I-BSA from the circulation by the liver (Moats \& Ramirez 1998), probably because of the culture conditions and the type of cell used. The ligand could occasionally be seen intracellularly as early as $15 \mathrm{~min}$ post-exposure, but the most clearly defined uptake occurred after $2 \mathrm{~h}$ exposure. E17 BSA:Au bound primarily to the plasma membranes of microvilli, but also bound in isolated patches of plasmalemma devoid of microvilli (Fig. 3). Intracellularly, the ligand was found in small coated and uncoated vesicles and also in larger uncoated vesicles resembling endosomes and/or multivesicular bodies (MVBs) (Fig. 4A and B). Colloidal gold was evident in large organelles (Fig. 5) that 

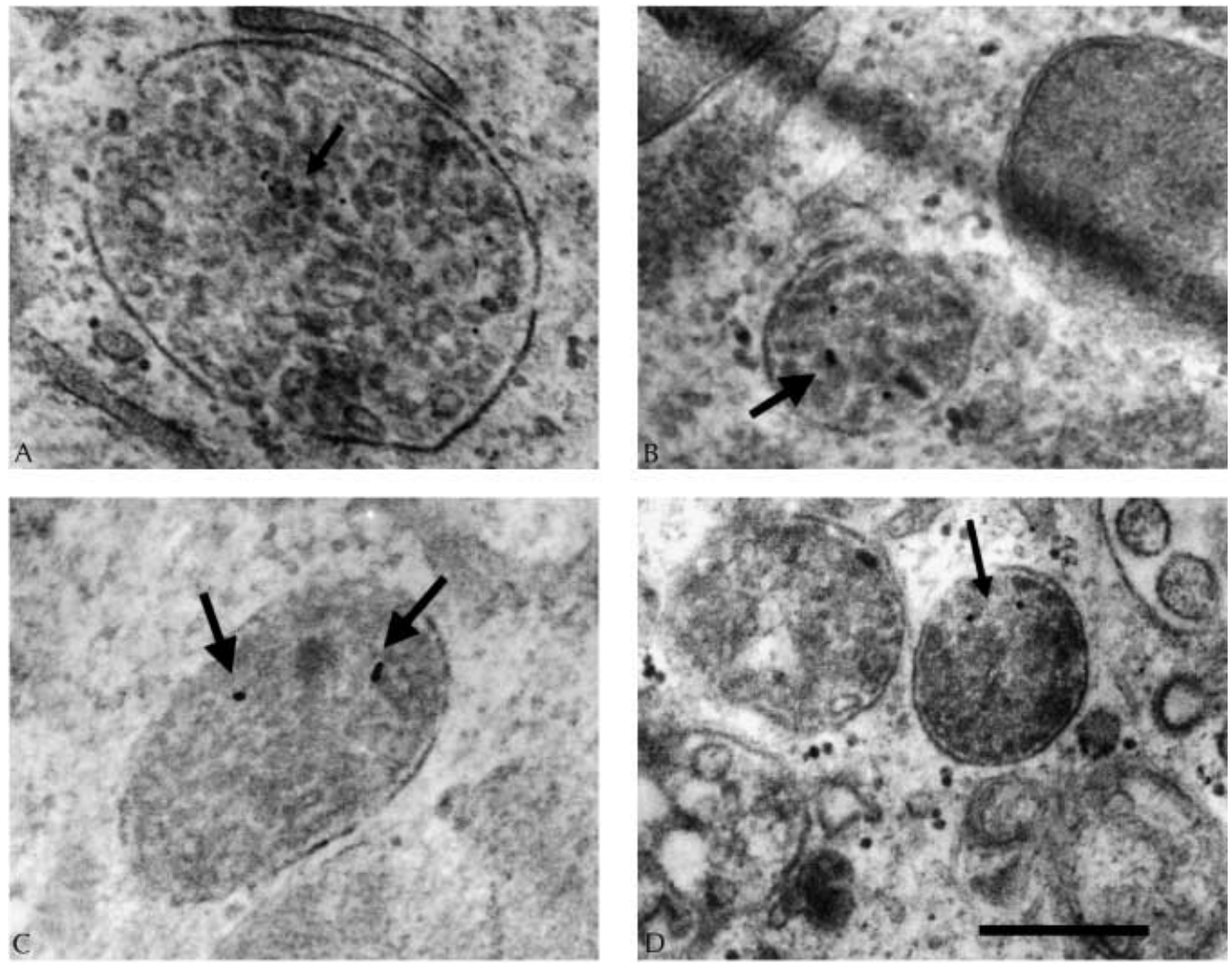

Figure 5 E17 BSA:Au was translocated from the plasma membranes of Hep G2 cells to intracellular organelles resembling multivesicular bodies (A) or vesicular mitochondria (B-D). (C, D) Note the clear presence of a double membrane, suggesting that these structures are mitochondria. Magnification $=80000 \times$. Scale bar $=0 \cdot 250 \mu \mathrm{m}$.

were similar to the vesiculated mitochondria found in the adrenal gland (Idelman 1970) and in other tissues undergoing anaerobic respiration (Shepard et al. 1998). Many of these organelles displayed clear outer and inner membranes (Fig. 4A, black arrow, and Fig. 5) like those commonly found in mitochondria. Most dramatically, E17 BSA:Au was found bound to plasma membranes directly overlying areas of coated pit formation (Fig. 6), indicating receptor-mediated endocytosis of this estrogen-containing ligand.

Similar experiments involving a BSA:colloidal gold conjugate (BSA:Au) failed to show this ligand intracellularly in the amount or distribution of E17 BSA:Au, despite an extracellular abundance of the ligand (Fig. $7 A$ and $B$ ); however, occasionally BSA:Au could be detected in MVBs and endosomes (Fig. 7B). Uptake of E17 BSA:Au could also be inhibited by preincubating the cells for $1 \mathrm{~h}$ with various potential competitors at $100 \mathrm{nM}$ concentrations (Table 2 and Fig. 8). E17 BSA and 17 $\beta$-estradiol both dramatically reduced the appearance of colloidal gold intracellularly (Fig. 8A and C). 17 $\alpha$-E6 BSA, 17 $\alpha-$ estradiol and a progesterone-BSA conjugate, P6 BSA, were ineffective competitors, as E17 BSA:Au could again be detected inside round organelles similar to vesiculated mitochondria (Fig. 8B and D) and in large, clear, endosome-like structures (Fig. 8B).

Exposure to cold profoundly inhibited the uptake and translocation of E17 BSA:Au by Hep G2 cells (not shown). Colloidal gold conjugates of either ligand were rarely found intracellularly in cells incubated for $2 \mathrm{~h}$ at $4{ }^{\circ} \mathrm{C}$ (not shown). Warming of the cooled cells to $37^{\circ} \mathrm{C}$, however, restored the transport of the ligand to the expected intracellular distribution (Figs 9-11). One hour of chasing at $37^{\circ} \mathrm{C}$ resulted in a significant difference between the uptake of E17 BSA:Au and that of BSA:Au in the different compartments. This difference was found, by Tukey analysis, to be due to the selective transport of E17 BSA:Au to MVBs, endosomes, lysosomes and transformed mitochondria (Fig. 9E). Note the presence of E17 BSA:Au in a coated vesicle with an approximate diameter of $177 \mathrm{~nm}$ (Fig. 9A), MVBs with tubular projections (Fig. 9B), and an elongated mitochondrion (Fig. 9C). A clear 


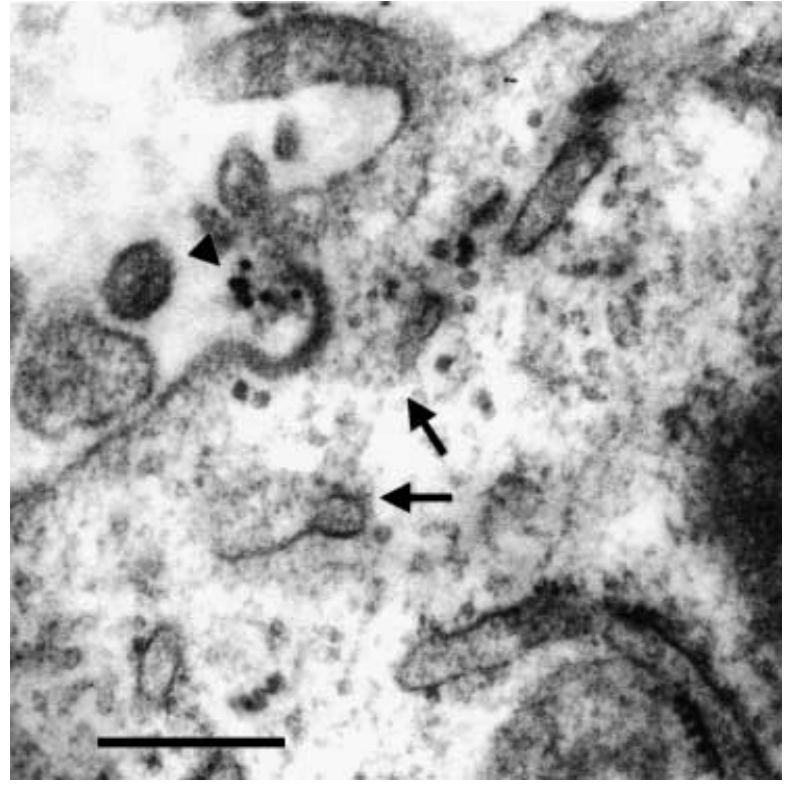

Figure 6 E17 BSA:Au is internalized by receptor-mediated endocytosis in Hep G2 cells. Note the clear presence of a clathrin coat on the endocytotic pit (arrow head) and intracellular tubulovesicular structures beneath the pit (small arrows). Magnification $=80000 \times$. Scale bar $=0.250 \mu \mathrm{m}$.

coated pit lacking BSA:Au is shown in Fig. 9D in spite of the presence of BSA:Au particles in the extracellular fluid. One and a half hours and $2 \mathrm{~h}$ at $37^{\circ} \mathrm{C}$ resulted in a
Table 2 Relative inhibition of E17BSA:Au uptake by Hep G2 cells in culture

\begin{tabular}{ll} 
& $\begin{array}{l}\text { Relative E17BSA } \\
\text { uptake }^{2}\end{array}$ \\
\cline { 2 - 2 } $\begin{array}{l}\text { Inhibitor } \\
\text { E17BSA }\end{array}$ & + \\
$17 \alpha-$-EBSA & +++ \\
$17 \beta$-Estradiol & + \\
$17 \alpha-$ Estradiol $^{2}$ & +++ \\
P6BSA $^{1}$ & +++
\end{tabular}

${ }^{1}$ P6BSA, 4-pregen-6B-ol-3, 20-dione hemisuccinate:BSA (Steraloids).

${ }^{2}+$, Present in few cells ( $10 \%$ of cells surveyed); +++ , present in most cells (>90\% of cells surveyed)

dramatic increase in the uptake of both ligands, but with a significant difference only between the amount of either ligand in the different compartments (Fig. 10E). However, despite the absence of an overall significant difference between the uptake of either ligand by all nine compartments, individual compartments did display preferential ligand uptake (i.e. uptake of BSA:Au by the lysosomes at $1.5 \mathrm{~h}$ (Fig. 10E) and by the endosomes and lysosomes at $2 \mathrm{~h}$ (Fig. 11E) and uptake of E17 BSA:Au by CURL structures and transformed mitochondria at $1.5 \mathrm{~h}$ and CURL structures at $2 \mathrm{~h}$ (Figs 10E and 11E). Examples of these different organelles containing gold particles are shown in Figs 10A-D and 11A-D (see the figure legends for details).
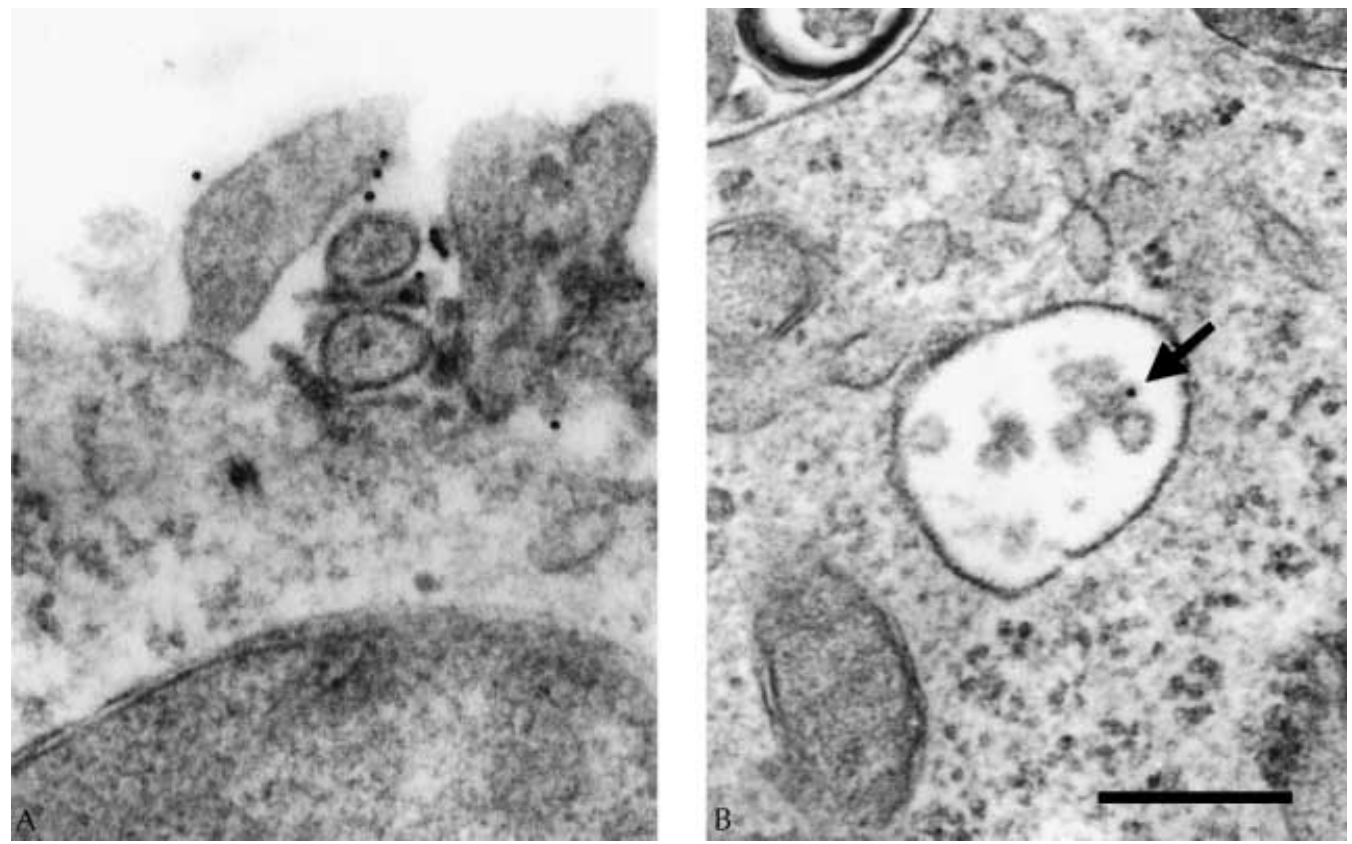

Figure 7 BSA:Au is minimally internalized by Hep G2 cells after $3 \mathrm{~h}$ incubation despite abundant ligand extracellularly (A). Occasionally, a small amount of ligand would be found intracellularly, either free in the cytosol or in MVBs (B). Magnification $=80000 \times$. Scale bar $=0 \cdot 250 \mu \mathrm{m}$. 

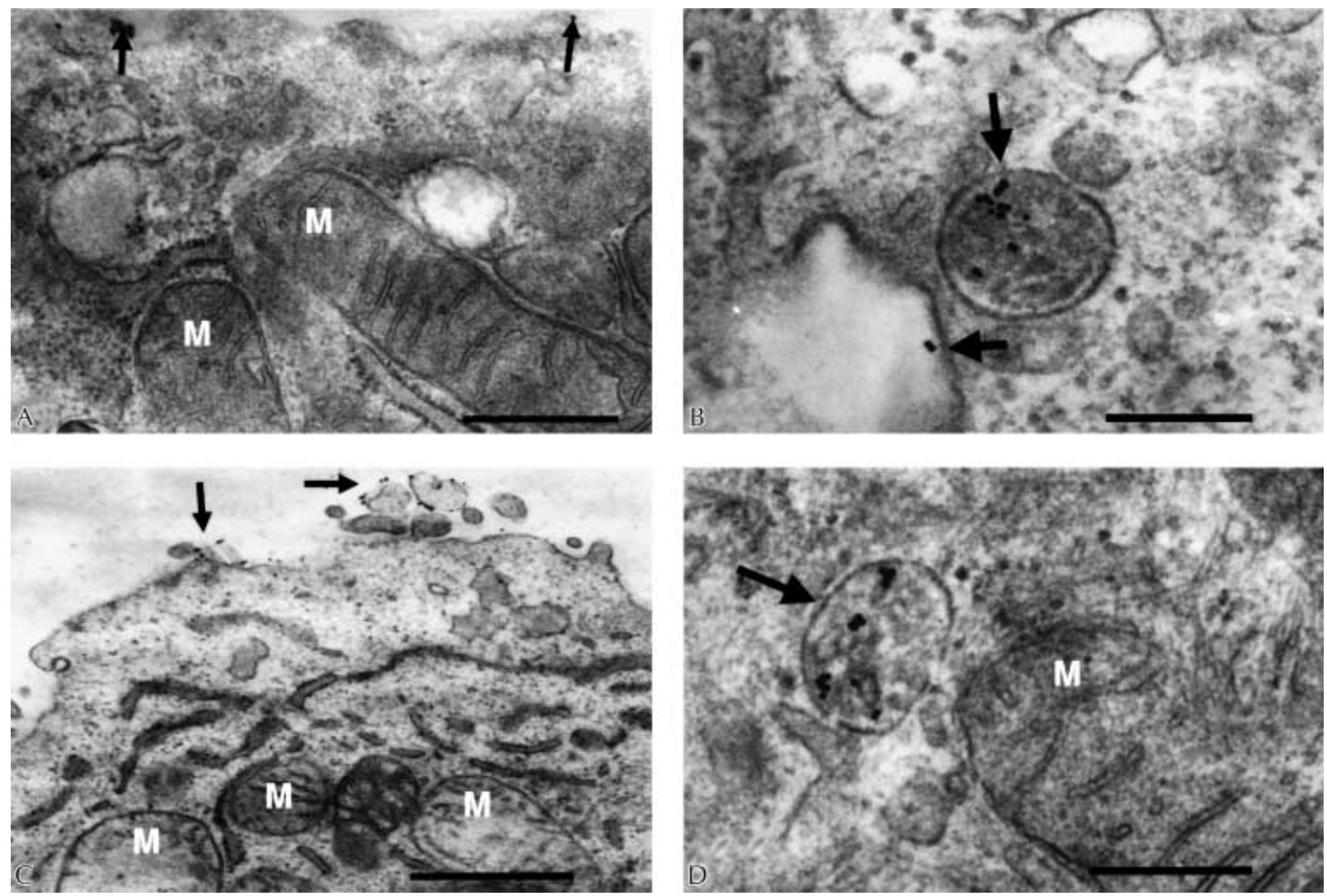

Figure 8 Internalization of E17 BSA:Au could be inhibited by E17 BSA (A) or 17ß-estradiol (C), in each case at $100 \mathrm{nM}$. (A, C) Note the absence of the ligand intracellularly. However, $100 \mathrm{nM} 17 \alpha$-E6 BSA (B) or P6 BSA (D) could not inhibit internalization of the ligand, as indicated by the presence of E17 BSA:Au intracellularly in mitochondria-like organelles and large, clear vesicles (arrows). These images suggest the presence of a specific and stereospecific membrane receptor for estradiol on the plasma membranes of Hep G2 cells. M, mitochondrion. Magnification: $40000 \times(A) ; 100000 \times(B) ; 20000 \times(C) ; 80000 \times(D)$. Scale bars: $0.5 \mu \mathrm{m}(A)$; $0 \cdot 2 \mu \mathrm{m}(\mathrm{B}) ; 1 \mu \mathrm{m}(\mathrm{C}) ; 0 \cdot 25 \mu \mathrm{m}(\mathrm{D})$.

The progression of the uptake and translocation of E17 BSA:Au to statistical significance is noteworthy. With one-way ANOVA, the minimal uptake and translocation of E17 BSA:Au into the different compartments is not statistically significant at $2 \mathrm{~h}$ at $4{ }^{\circ} \mathrm{C}(P=0 \cdot 64)$. However, as time of chasing of the gold particles at $37^{\circ} \mathrm{C}$ increases, the distribution of E17 BSA:Au in the nine compartments becomes progressively more statistically significant, reaching $P=0.002$ at $2 \mathrm{~h}$ at $37^{\circ} \mathrm{C}$. BSA:Au does not display this progression; however, at one time point $-1 \mathrm{~h}$ at $37^{\circ} \mathrm{C}-$ the distribution of BSA:Au over the nine compartments is highly significant $(P=0 \cdot 001)$, but this effect does not continue for the later time points.

The uptake of E17 BSA:Au and BSA:Au by cells exposed to $37^{\circ} \mathrm{C}$ for less than $1 \mathrm{~h}$ was also investigated (see Table 3 for data). Significant differences were found between the numbers of E17 BSA:Au particles and BSA:Au particles in coated vesicles $(\mathrm{CVs})$ and CURL vesicles after $15 \mathrm{~min}$ at $37^{\circ} \mathrm{C}$. After $30 \mathrm{~min}$ of incubation at $37{ }^{\circ} \mathrm{C}$, significant differences were found between the contents of the two ligands in uncoated vesicles and endosomes. Forty-five minutes at $37^{\circ} \mathrm{C}$ produced significant increases in the E17 BSA:Au content of uncoated vesicles and CURL vesicles, whereas at this same time point, the BSA:Au contents of MVBs and endosomes were significantly higher than their E17 BSA contents. In general, E17 BSA:Au was found in endocytotic vesicles after short-term incubation at $37^{\circ} \mathrm{C}(15-45 \mathrm{~min})$, and in larger MVBs, endosomes and mitochondria at later time points (see Table 3 and Figs 9-11). In contrast, BSA:Au was found in a smaller amount in endocytic vesicles after short-term incubation and was then transported to the endosomes and lysosomes and not to the mitochondria.

The identities of the presumed mitochondria were investigated more thoroughly by incubating cells labeled with either E17 BSA:Au or BSA:Au with a solution of cytochrome $c$ and $\mathrm{DAB}$, which stains mitochondria 


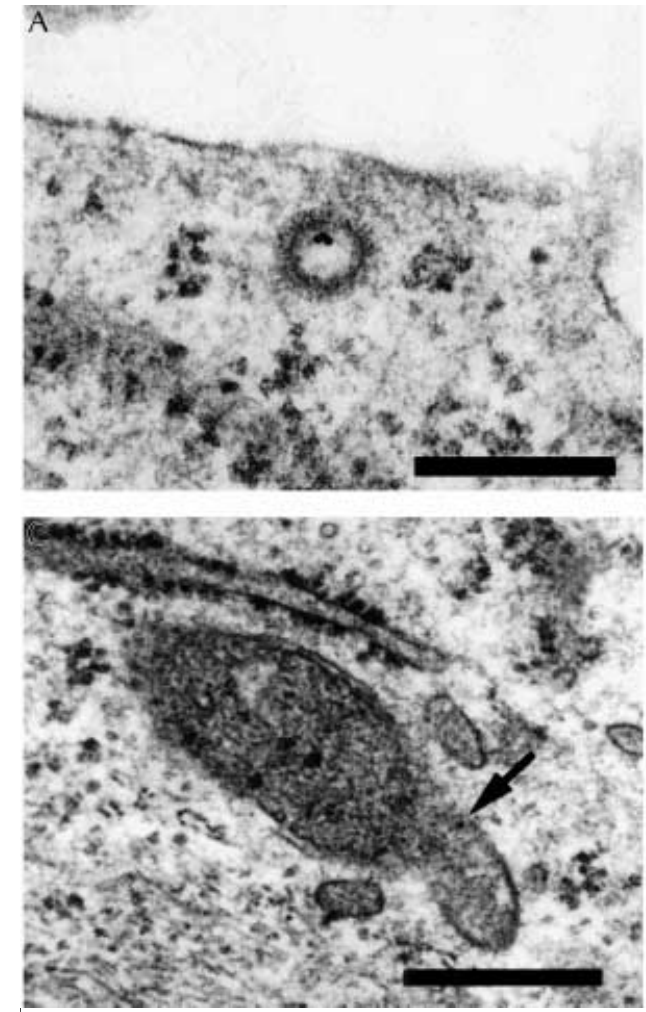

E Ligands significantly different by 2-way ANOVA (p=0.04)
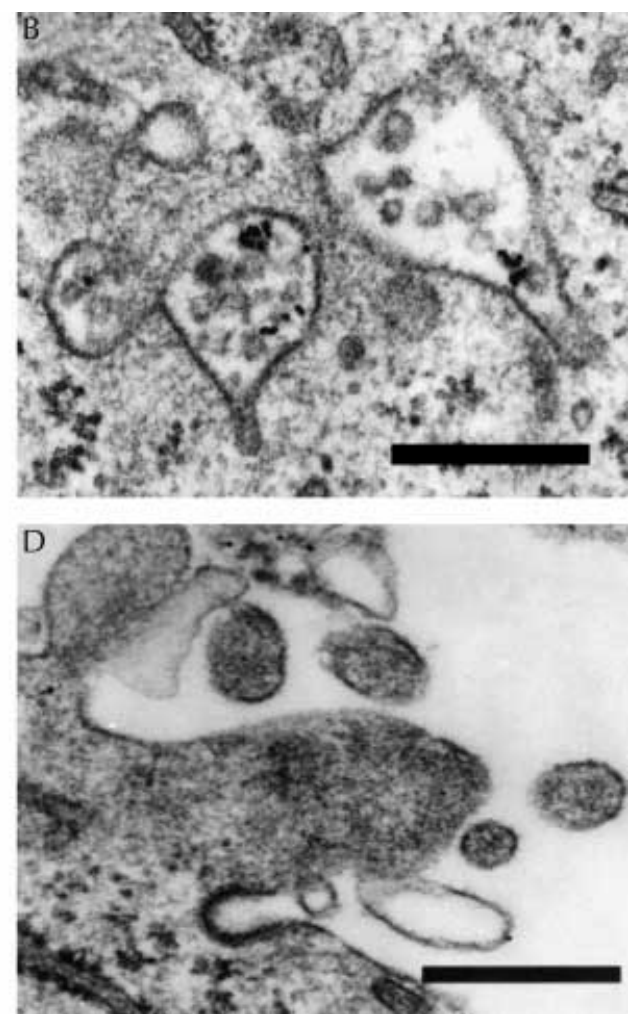

E17BSA: Au

$\triangle$ BSA: Au

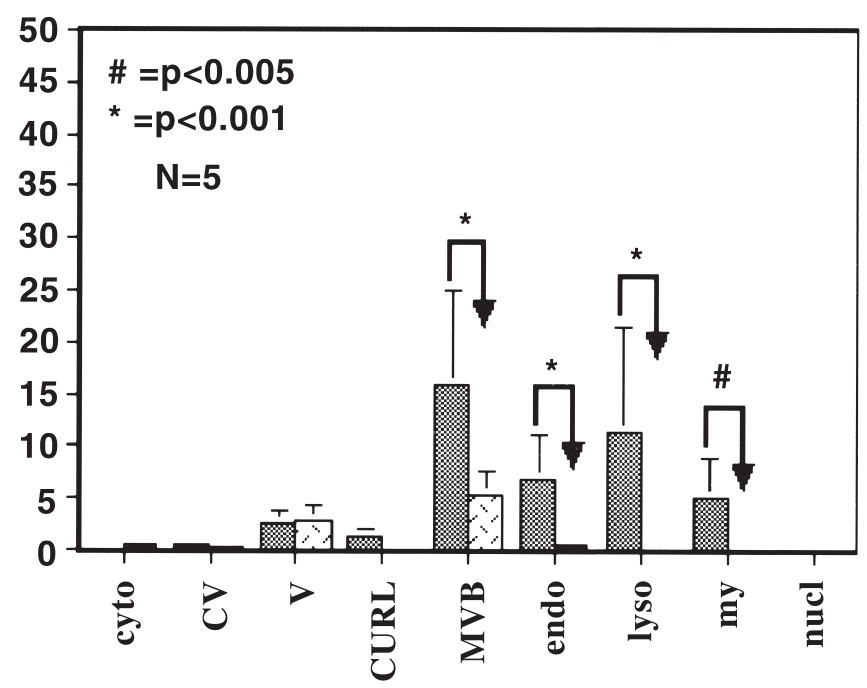

Compartment 
(Angermüller et al. 1998). Only cells labeled with E17 $\mathrm{BSA}: \mathrm{Au}$ displayed the ligand in close apposition to clearly stained, non-vesiculated mitochondria. In many cases the ligand was found in vesicles that were in contact with mitochondria (Fig. 12A and B) or fusing with mitochondia (Fig. 12C).

\section{Discussion}

It is well known that estrogen, like other steroid hormones, has effects that are not explained by the classical mechanism of steroid hormone action (cf. Ramirez 1996, Wehling 1997). In particular, these events occur over a time course too rapid to be caused by an alteration in transcription, or in situations in which translation is repressed (Lagrange et al. 1997) or the steroid receptor is absent ( $\mathrm{Gu}$ et al. 1999).

A potential explanation of these 'non-genomic' actions of steroids is the presence of one or more plasma-membrane-bound binding sites or putative receptors for the steroid. Binding sites for estrogen have already been reported for several cells and tissues including the liver (Moats \& Ramirez 1998) and hepatocytes (Pietras \& Szego 1979), endometrium (Pietras \& Szego 1977), osteoblasts (Massas et al. 1998), the pituitary (Bression et al. 1986) and various brain regions (Zheng \& Ramirez 1997). Here, we elaborate on previously published results (Moats \& Ramirez 1998) in which the livers of immature female rats were identified as sites of rapid uptake of a membraneimpermeant estrogen-BSA conjugate, by directly visualizing the uptake and subsequent translocation of a colloidal gold conjugate of this ligand in cultured Hep G2 cells.

Isolated plasmalemmal/microsomal membranes (P3 fraction) from Hep G2 human hepatoblastoma cells bind E17 ${ }^{125}$ I-BSA specifically with high affinity $\left(K_{\mathrm{d}}=1 \cdot 26 \mathrm{nM}\right.$; $B_{\max }=68 \mathrm{pmol} / \mathrm{mg}$ protein). This ligand blocks the hydroxyl group in position 17 but leaves the 3-hydroxyl free for receptor binding (Zheng \& Ramirez 1999a). A second ligand, conjugated at the 6 position of estradiol, 17 $\beta$-E6 BSA, was as good, or better than, the homologous competitor; however, a form of this ligand containing $17 \alpha-$ estradiol, 17 $\alpha$-E6 BSA, was a poor competitor. These data indicate that at least one binding site for the more biologically active form of estradiol may be present on Hep
G2 hepatic tumor cell plasma membranes, consistent with results from normal liver P3 fractions (Moats \& Ramirez 1998). Normal liver P3 fractions, however, contain two detected binding sites of high affinity/low capacity and low affinity/high capacity, both having identical affinity for either E6 BSA or E17 BSA. It is unknown, however, which of these sites mediates the uptake of the conjugate ligand.

E1 $7^{125}$ I-BSA is removed from the medium by Hep G2 cells in culture and is translocated from plasmalemmal/ microsomal membranes to mitochondrial/lysosomal membranes in much the same fashion as $\mathrm{E} 6^{125} \mathrm{I}-\mathrm{BSA}$ is translocated by the liver in vivo (Moats \& Ramirez 1998). As the amount of binding sites ( $\mathrm{fmol} / \mathrm{mg}$ protein) in association with the $\mathrm{P} 2$ fraction increased, the amount in the P3 fraction decreased, this divergence becoming significantly different by $60 \mathrm{~min}$. In contrast, the radioactivity in the nuclear fraction (P1) did not change significantly as a function of time of incubation; this is similar to previous results obtained in vivo (Moats \& Ramirez 1998). As expected from the in vivo data (Moats \& Ramirez 1998), the uptake of ${ }^{125}$ I-BSA by Hep G2 cells was minimal and did not occur in a manner similar to that of E1 $7^{125}$ I-BSA (see Table 1). The dramatic differences between the amounts of uptake and distribution of the two ligands may be indicative of a membrane-mediated uptake system that is selective for estrogen.

Unlike the P1 fractions collected from in vivo experiments (Moats \& Ramirez 1998), the P1 fractions from Hep G2 cell membranes contained significant radioactivity from the E1 ${ }^{125}$ I-BSA ligand that led to apparent higher numbers of binding sites in this fraction. Experiments using ${ }^{125}$ I-BSA showed the relative proportion of radioactivity in P1 fractions labeled with this ligand (range: $38-44 \%$ ) to be similar to the relative proportion of radioactivity in $\mathrm{P} 1$ fractions labeled with $\mathrm{E} 17^{125} \mathrm{I}-\mathrm{BSA}$ (range: $37-43 \%$ ). Since evidence in vivo demonstrated that estrogen-BSA conjugates were not transported to the cell nucleus, it is unlikely that BSA is transported there. Furthermore, the relative proportion of the radioactivity in the P1 fractions labeled with either ligand is the same, suggesting that the excessive radioactivity in the P1 fraction may be due to incomplete homogenization of the cells, contamination by the other fractions, or other forms of non-specific association of the ligands.

\footnotetext{
Figure $9 \mathrm{Hep} \mathrm{G2}$ cells in culture were preincubated 30 min at $4{ }^{\circ} \mathrm{C}$ and then exposed to either E17 BSA:Au or BSA:Au for $1 \mathrm{~h}$ at $4{ }^{\circ} \mathrm{C}$ followed by $1 \mathrm{~h}$ at $37{ }^{\circ} \mathrm{C}$ with gentle agitation; cells were then fixed for electron microscopy and the gold particles counted in five randomly selected cells. Two-way ANOVA detected a significant difference in the number of particles of the two ligands, regardless of the compartment. Tukey analysis revealed significant differences in the numbers of particles of E17 BSA:Au relative to BSA:Au for MVBs, endosomes, lysosomes and transformed mitochondria, suggesting preferential uptake and transport of this ligand via receptor-mediated mechanisms. (A-C) Cells treated with E17 BSA:Au. This ligand could be found in coated vesicles (A), MVBs and CURL organelles (B), and organelles resembling transformed mitochondria (C). (Magnification: $60000 \times(\mathrm{A}, \mathrm{B}) ; 100000 \times(\mathrm{C})$. Scale bars: 0.333 $\mu \mathrm{m}(\mathrm{A}, \mathrm{B}) ; 0 \cdot 2 \mu \mathrm{m}$ (C). (D) Cells treated with BSA:Au. Magnification $=80000 \times$; scale bar $=0.25 \mu \mathrm{m}$ ). Note the gold particles in the extracellular fluid. (E) A graphical representation of the average $( \pm$ S.E.) number of gold particles per subcellular compartment. Abbreviations: cyto, gold particles free in the cytoplasm; CV, coated vesicles; V, vesicular structures; CURL, compartment of uncoupling receptor and ligand; MVB, multivesicular bodies; endo, endosomes; lyso, lysosomes; mt, transformed mitochondria; nucl, nucleus.
} 

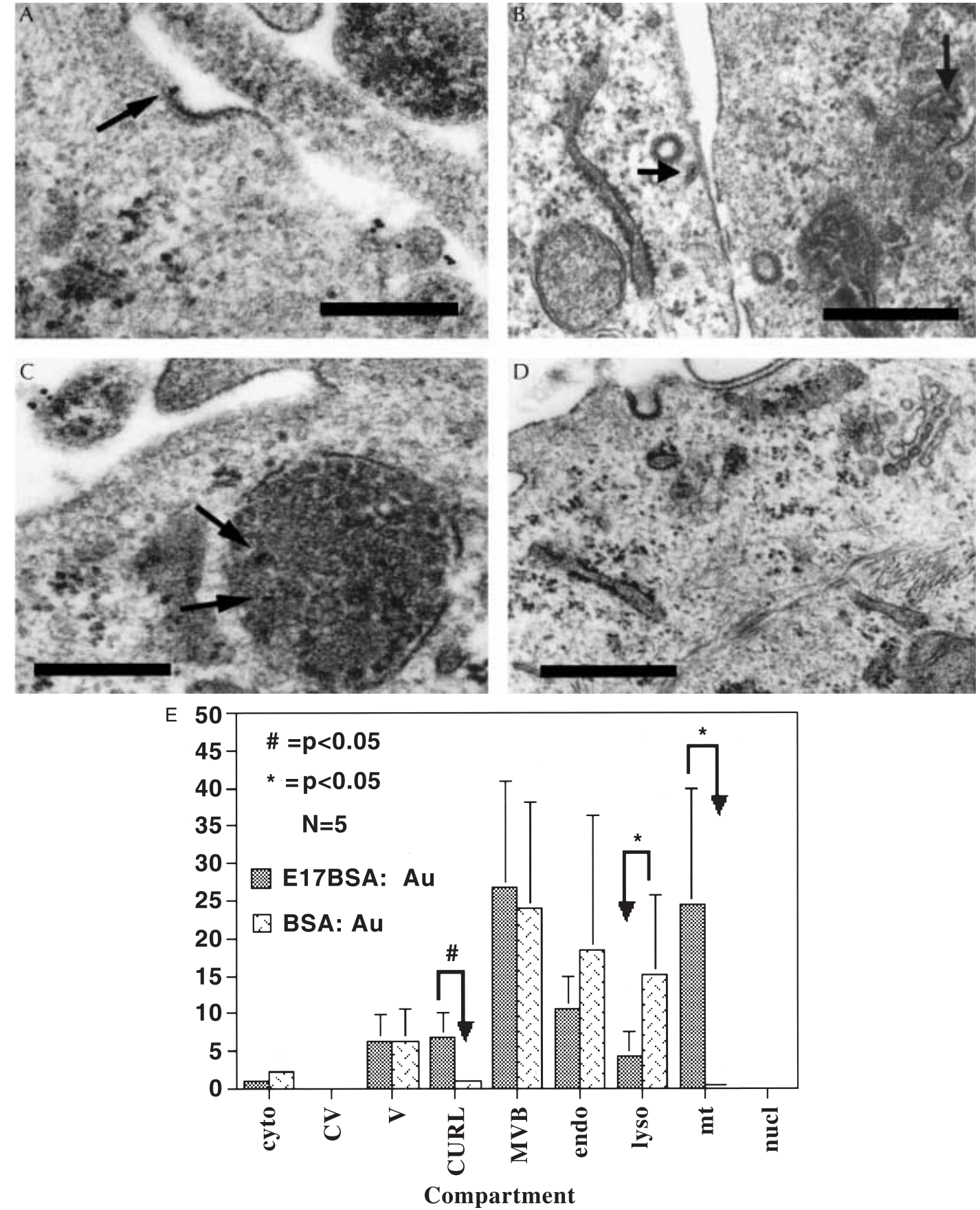

Figure $10 \mathrm{Hep} \mathrm{G} 2$ cells in culture were preincubated for $30 \mathrm{~min}$ at $4{ }^{\circ} \mathrm{C}$ and then exposed to either E17 BSA:Au or BSA:Au for 0.5 h at $4{ }^{\circ} \mathrm{C}$ followed by $1.5 \mathrm{~h}$ at $37{ }^{\circ} \mathrm{C}$ with gentle agitation, fixed for electron microscopy, and the gold particles were counted in five randomly selected cells. Although overall significant differences were not shown by two-way ANOVA, a Tukey analysis of individual compartments did uncover differences in the numbers of particles of E17 BSA:Au and BSA:Au. (A-C) Cells treated with E17 BSA:Au. This ligand could be found in coated pits (A), uncoated vesicles and MVBs (arrows in $B$ ), and organelles resembling transformed mitochondria (C). Magnification: $100000 \times(\mathrm{A}, \mathrm{C}) ; 60000 \times(\mathrm{B})$. Scale bars: $0 \cdot 2 \mu \mathrm{m}(\mathrm{A}, \mathrm{C}) ; 0 \cdot 33 \mu \mathrm{m}(\mathrm{B})$. (D) Cells treated with BSA:Au. Magnification= $30000 \times$. Scale bar $=0.66 \mu \mathrm{m}$. Note the absence of gold particles in this cell in spite of the formation of a well-defined coated pit. (E) A graphical representation of the average ( \pm S.E.) number of gold particles per subcellular compartment (as listed in Fig. 9). 

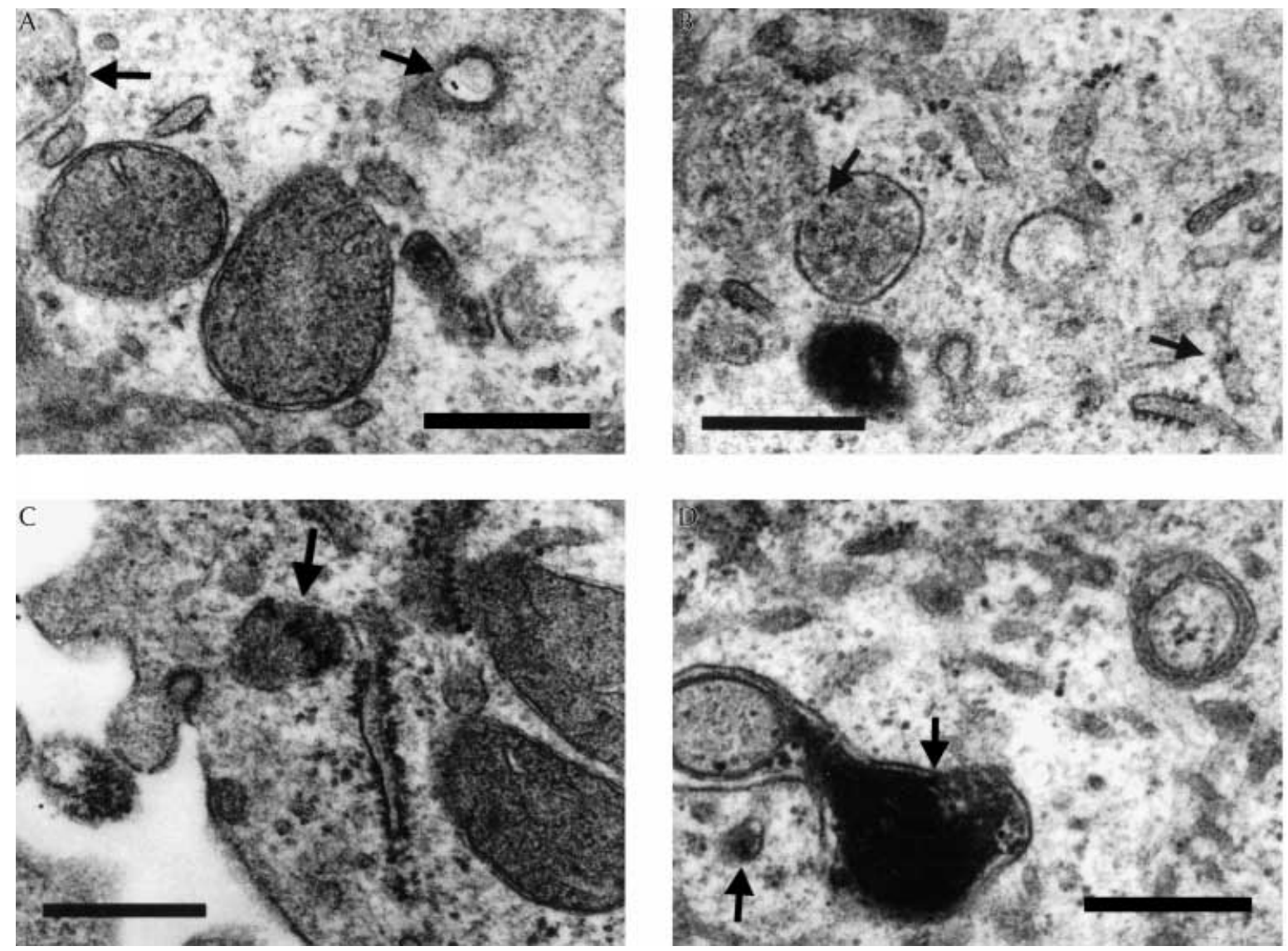

\section{E Compartments significantly different by 2-way ANOVA $(\mathbf{p}=\mathbf{0 . 0 0 2})$

\author{
Q BSA:Au
}

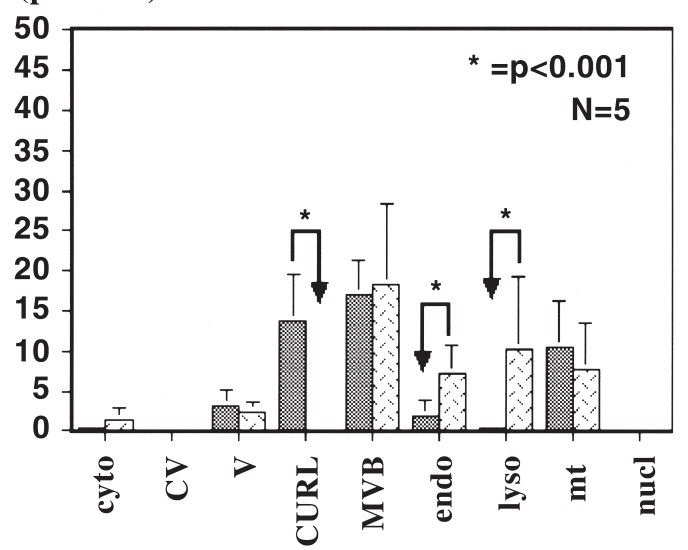

\section{Compartment}

Figure 11 Hep G2 cells in culture were preincubated for 30 min at $37^{\circ} \mathrm{C}$, exposed to either E17 BSA:Au or BSA:Au for $2 \mathrm{~h}$ at $37^{\circ} \mathrm{C}$ with gentle agitation, treated for electron microscopy, and the gold particles counted in five randomly selected cells. (A-C) Cells treated with E17 BSA:Au. This ligand could be found in the CURL and MVBs $(A)$ and organelles resembling mitochondria in transformation $(B, C)$; $(B)$ note the apparent extrusion of matrix and the presence of gold particles in a tubular structure. Magnification: $80000 \times(A) ; 100000 \times(B) ; 60000 \times(C)$. Scale bars: $0 \cdot 25 \mu \mathrm{m}(\mathrm{A}) ; 0 \cdot 2 \mu \mathrm{m}(\mathrm{B}) ; 0 \cdot 33 \mu \mathrm{m}$ (C). (D) Cells treated with BSA:Au. This ligand was found primarily in the lysosomes. Magnification $=60000 \times$. Scale bar $=0 \cdot 33 \mu \mathrm{m}$. (E) A graphical representation of the average ( \pm S.E.) number of gold particles counted per subcellular compartment (as listed in Fig. 9). 
Table 3 Uptake of E17BSA:Au or BSA:Au by Hep G2 cells in culture after various lengths of time at $37^{\circ} \mathrm{C}$ (av. particle number \pm S.E.M.; $n=5)$

\begin{tabular}{|c|c|c|c|c|c|c|}
\hline & & Time at 37 & & & & \\
\hline & Ligand & 15 & 30 & 45 & 60 & 90 \\
\hline $\begin{array}{l}\text { Subcel } \\
\text { compa }\end{array}$ & & & & & & \\
\hline Cyto & E17BSA:Au & $0 \cdot 6 \pm 0 \cdot 4$ & $0 \cdot 2 \pm 0 \cdot 2$ & $1 \cdot 6 \pm 0 \cdot 5$ & 0 & $1 \pm 0$ \\
\hline & BSA:Au & $1 \pm 0 \cdot 4$ & $1 \pm 0 \cdot 8$ & $1 \pm 1$ & $0 \cdot 6 \pm 0 \cdot 4$ & $2 \cdot 2 \pm 0 \cdot 7$ \\
\hline V & E17BSA:Au & $5 \cdot 6 \pm 2 \cdot 3$ & $12 \cdot 8 \pm 2 \cdot 9^{2}$ & $10 \cdot 6 \pm 2 \cdot 3^{2}$ & $2 \cdot 6 \pm 1 \cdot 25$ & $6 \cdot 4 \pm 4 \cdot 5$ \\
\hline & $\mathrm{BSA}: \mathrm{Au}$ & $5 \pm 1 \cdot 6$ & $2 \cdot 4 \pm 1 \cdot 2^{2}$ & $2 \cdot 8 \pm 1 \cdot 7^{2}$ & $2 \cdot 8 \pm 1 \cdot 5$ & $6 \cdot 2 \pm 4 \cdot 5$ \\
\hline $\mathrm{CVs}$ & E17BSA:Au & $2 \cdot 4 \pm 1 \cdot 5^{2}$ & 0 & 0 & $0.6 \pm 0.6$ & 0 \\
\hline & BSA:Au & $0^{2}$ & $0 \cdot 6 \pm 0 \cdot 4$ & $1 \cdot 2 \pm 1 \cdot 2$ & $0 \cdot 2 \pm 0 \cdot 2$ & 0 \\
\hline CURL & E17BSA:Au & $2 \cdot 4 \pm 1 \cdot 1^{2}$ & $5 \cdot 4 \pm 2 \cdot 9$ & $2 \cdot 2 \pm 0 \cdot 7^{2}$ & $1 \cdot 2 \pm 0 \cdot 8$ & $6 \cdot 8 \pm 3 \cdot 4^{2}$ \\
\hline & BSA:Au & $0^{2}$ & $2 \cdot 2 \pm 1 \cdot 6$ & $1 \pm 0 \cdot 8^{2}$ & 0 & $1 \pm 0 \cdot 55^{2}$ \\
\hline MVBs & E17BSA:Au & $2 \cdot 2 \pm 1 \cdot 7$ & $6 \cdot 4 \pm 3 \cdot 6$ & $1 \pm 1^{2}$ & $15 \cdot 8 \pm 9 \cdot 2^{2}$ & $26 \cdot 8 \pm 14 \cdot 1$ \\
\hline & BSA:Au & $3 \cdot 4 \pm 1 \cdot 9$ & $8 \cdot 8 \pm 3 \cdot 9$ & $18 \cdot 6 \pm 7 \cdot 7^{2}$ & $5 \cdot 4 \pm 2 \cdot 2^{2}$ & $24 \pm 14 \cdot 2$ \\
\hline Endo & E17BSA:Au & 0 & $0^{2}$ & $0^{2}$ & $6 \cdot 8 \pm 4 \cdot 2^{2}$ & $10 \cdot 6 \pm 4 \cdot 4$ \\
\hline & BSA:Au & 0 & $4 \cdot 8 \pm 4 \cdot 1^{2}$ & $2 \cdot 8 \pm 1 \cdot 7^{2}$ & $0 \cdot 6 \pm 0.6^{2}$ & $18 \cdot 4 \pm 18$ \\
\hline Lyso & E17BSA:Au & 0 & 0 & 0 & $11 \cdot 4 \pm 10 \cdot 1^{2}$ & $4 \cdot 4 \pm 3 \cdot 1^{2}$ \\
\hline & BSA:Au & $0.4 \pm 0.4$ & $0 \cdot 4 \pm 0 \cdot 4$ & $1 \pm 1$ & $0^{2}$ & $15 \cdot 2 \pm 10 \cdot 6^{2}$ \\
\hline Mt & E17BSA:Au & 0 & 0 & 0 & $5 \cdot 0 \pm 3 \cdot 8^{2}$ & $24 \cdot 6 \pm 15 \cdot 3^{2}$ \\
\hline & BSA:Au & 0 & 0 & 0 & $0^{2}$ & $0 \cdot 6 \pm 0 \cdot 6^{2}$ \\
\hline Nucl & E17BSA:Au & 0 & 0 & 0 & 0 & 0 \\
\hline & BSA:Au & 0 & 0 & 0 & 0 & 0 \\
\hline
\end{tabular}

${ }^{1}$ Abbreviations: Cyto, cytoplasm; V, vesicular structures; CVs, coated vesicles; CURL, compartment of uncoupling receptor and ligand; MVBs, multivesicular bodies; Endo, endosomes; Lyso, lysosomes; Mt, transformed mitochondria; Nucl, nucleus.

${ }^{2}$ Significantly different numbers of gold particles between the two ligands, according to ANOVA followed by Tukey test $(P<0 \cdot 05)$.

Although differential centrifugation of radioactively labeled cell and tissue samples has been used extensively to demonstrate intracellular targets for a particular ligand, in the case of this novel pathway of estrogen uptake, a more definitive identification of the intracellular location of the ligand is necessary. To achieve this, E17 BSA was adsorbed to colloidal gold (E17 BSA:Au), incubated with intact Hep G2 cells in culture, and the cells processed for electron microscopy. The ligand occasionally could be observed intracellularly within $5 \mathrm{~min}$ post-exposure (not shown); however, the most dramatic intracellular distribution occurred 1-2 h post-exposure.

As predicted by the results of experiments with the radioactive form of this ligand, E17 BSA:Au was shown to attach to the plasma membranes of Hep G2 cells, an effect that occurred minimally with a BSA:colloidal gold conjugate. The translocation of the ligand from the cell membrane to the cell interior was temperature-dependent and could be inhibited not only by free E17 BSA but also by $17 \beta$-estradiol (in each case at $100 \mathrm{nM}$ ). This active uptake mechanism of E17 BSA:Au could not be inhibited by $17 \alpha$-E6 BSA, 17 $\alpha$-estradiol or the progesterone conjugate P6 BSA. Commonly, clusters of E17 BSA:Au were viewed in areas of clathrin-coated pit formation and in clathrin-coated vesicles. This is consistent with the results of Garcia-Segura et al. (1987), in which $17 \beta$-estradiol was shown to rapidly (within $1 \mathrm{~min}$ ) increase the number of exo-endocytic pits on rat arcuate nucleus neuron plasma membranes. Clathrin assembly is dependent on the binding of adaptor proteins (APs) to activated receptors or association with specific, receptor-activated AP binding sites (Schmid 1997), a process that has been extensively studied using the epidermal growth factor (EGF) receptor (Sorkin \& Carpenter 1993, Sorkina et al. 1999). In view of the specificity of the binding, the sensitivity of the uptake to cold temperatures and the presence of clathrin at many membrane binding sites, an active process, probably receptor-mediated, must occur at the plasma membranes of Hep G2 cells to achieve the internalization of estradiolcontaining ligands.

The estrogen-BSA-colloidal gold-conjugate ligand was rapidly internalized via coated and uncoated vesicles and transported to larger vesicular structures resembling the sorting or tubulovesicular endosome or CURL (Geuze et al. 1983). In contrast, the uptake of BSA, although minimal, occurred primarily via uncoated vesicles, which do not involve the CURL; this is consistent with recent results of Synnes et al. (1999). This intracellular structure was originally described by Geuze et al. (1983) as a 'compartment for uncoupling receptor and ligand' for the asialoglycoprotein receptor. Acidic conditions inside these endosomes dissociate the ligand from internalized receptors and then these components are separated to different locations in the endosome by ill-defined mechanisms. The ligand is then usually transported by tubulovesicular structures to the lysosomes for degradation, while the receptor 

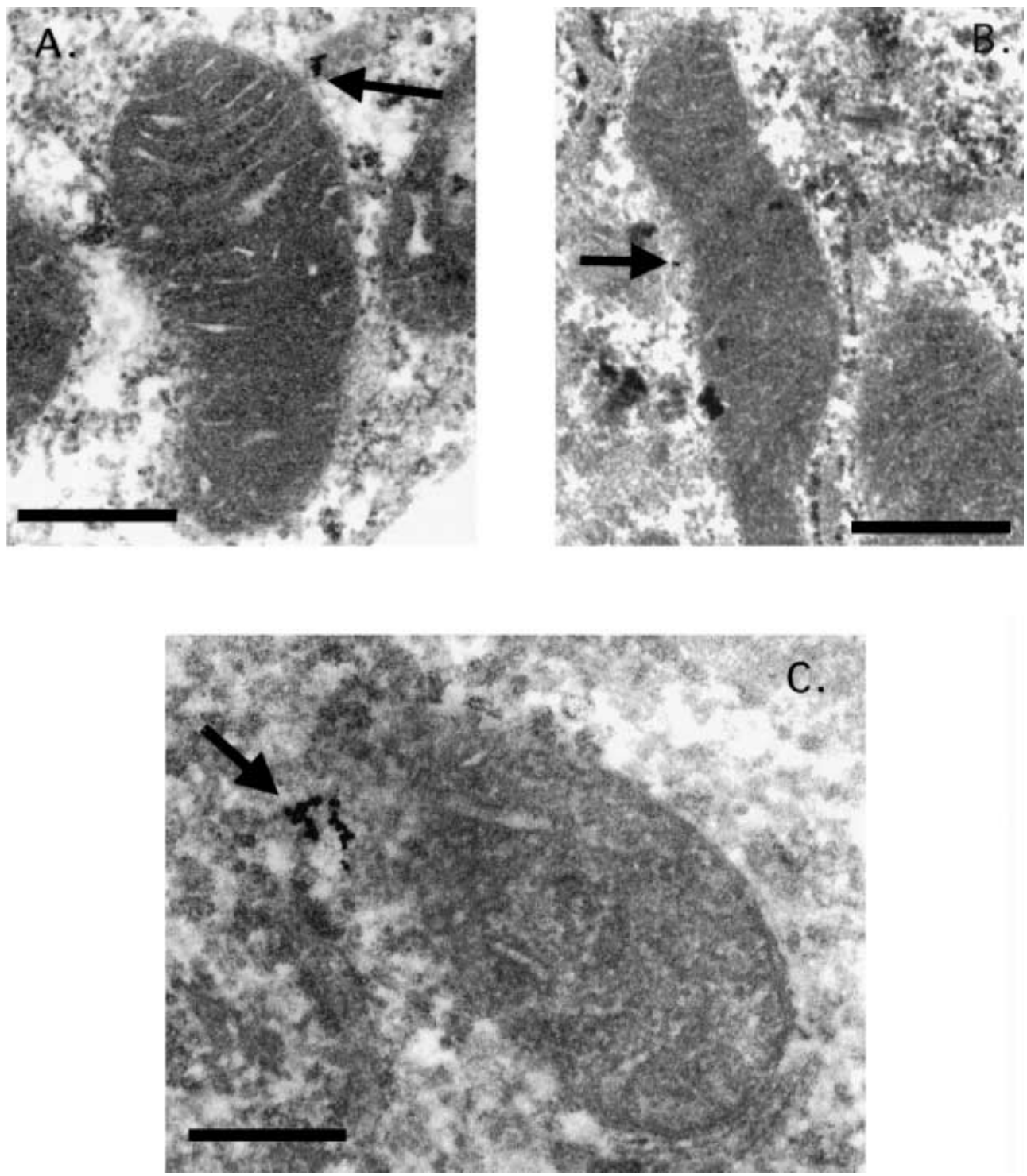

Figure 12 Hep G2 cells in culture were exposed to E17 BSA:Au for $3 \mathrm{~h}$ and fixed for electron microscopy as described in the Materials and Methods. Following fixation, the cells were incubated for $30 \mathrm{~min}$ with a solution of $0 \cdot 05 \%$ cytochrome $c$ and $15 \mathrm{mg} / \mathrm{ml}$ DAB in $0 \cdot 1 \mathrm{M}$ PBS containing $0 \cdot 1 \%$ Triton X-100, according to the method of Angermüller et al. (1998). This incubation is effective in labeling mitochondria with a dark stain, increasing their visibility and facilitating identification. E17 BSA:Au could be found in small vesicles in close association with positively labeled mitochondria (arrows in Fig. A-C). The vesicles could then fuse with the mitochondrial membrane and deliver their estrogen-containing 'cargo', as appears to be the case here (C). These images support the original conclusion that translocation of estrogen-BSA in Hep G2 cells is an active process and involves delivery to mitochondria rather than lysosomes. (A, B) Magnification $=40000 \times$. Scale bar $=0.5 \mu \mathrm{m}$. (C) Magnification $=100000 \times$. Scale bar $=0.2 \mu \mathrm{m}$.

may be either recycled back to the plasma membrane or degraded by the lysosomes. Although the sorting signals for the receptor and the ligand are unknown, recently, the clathrin-associated APs have been shown to remain bound to the internalized EGF receptors even after clathrin dissociation and fusion to the CURL (Sorkina et al. 1999). This suggests that the APs (or their components) may be involved in sorting and also even in translocation of ligands to intracellular sites other than the lysosomes.

Szego \& Pietras (1981) proposed a membrane receptormediated uptake and translocation scheme for estradiol which involved delivery of the steroid first to lysosomes, then potentially to the mitochondria as well as the nucleus. E17 BSA:Au was not primarily transported to secondary 
lysosomes, as has been shown for many ligands, and was never transported to the nucleus during the $2 \mathrm{~h}$ time course of the experiments; rather, it was transported to organelles resembling vesiculated mitochondria or mitochondria undergoing transformation. Vesiculated mitochondria are indicative of anaerobic respiration (Shepard et al. 1998), and estradiol has been shown to inhibit the activity of the mitochondrial F1/F0 ATPase-synthase (Zheng \& Ramirez 1999a) - essentially the final step in the electron transport chain. Furthermore, estradiol may rapidly modify mitochondrial calcium flux, increasing calcium uptake (Troyan et al. 1997). Although it is not known if E17 BSA:Au is the cause of the potential change in mitochondrial morphology, it is possible that this complex may be altering mitochondrial physiology in extreme ways, leading to dramatic changes in activity and appearance. This is likely given that E17 BSA:Au was delivered to apparently healthy mitochondria with clear lamellar cristae (see Fig. 12). Importantly, despite the potential effect on mitochondrial morphology, incubation of cells with E17 BSA:Au did not alter overall cell morphology when compared with unexposed cells or cells incubated with BSA:Au (not shown).

Recent reports by Razandi et al. (1999) and Norfleet et al. (1999) have suggested that a single estrogen-receptor transcript could correspond to both the intracellular and membrane estrogen receptors (ERs). However, it is unlikely that estrogen receptor $\alpha(E R \alpha)$ is responsible for the binding and uptake in these Hep G2 cells, as they do not express ER $\alpha$ (Mattick et al. 1997). The expression of estrogen receptor $\beta(E R \beta)$ in these cells is undetermined; however, the liver does not express ER $\beta$ (Enmark et al. 1997). Moreover, SDS-PAGE of isolated Hep G2 P3 fractions followed by ligand blotting with E1 $17^{125}$ I-BSA or E17 BSA:Au does not reveal proteins with molecular weights similar to that of the ERs (Moats \& Ramirez 1999). The presence of an unmodified form of ER in the plasma membrane presumably would not allow for the direct interaction of APs, leading to clathrin binding and endocytosis. If a form of the ER is present in the plasma membrane, however, it could potentially interact with other membrane proteins upon binding ligand (Ramirez et al. 1996, Marino et al. 1998), leading to internalization via clathrin- or non-clathrin-facilitated endocytosis. Despite these possibilities, we believe that the protein (or proteins) responsible for the uptake of E17 BSA ligands in rat liver and Hep G2 cells is unrelated to the intracellular ER but shares similar natural ligands.

In summary, we have shown here, through electron microscopic visualization, the binding and uptake of estrogen-BSA-gold complexes to intact Hep G2 cells in culture. Upon binding to the plasma membrane, the ligand is rapidly internalized via clathrin-coated vesicles and is transported to sorting endosomes. Interestingly, the ligand is then translocated to organelles resembling vesiculated mitochondria and also occasionally to the lysosomes.
Most importantly, the estrogen-containing ligand is never observed in the nucleus. These data, as well as published data on the actions of estrogen on mitochondria (Troyan et al. 1997), may lead to the following model. Estrogen, free or in association with plasma or media proteins such as albumin or sex-hormone-binding globulin (Rosner 1991) binds to a specific receptor site on the plasma membranes of target cells. The activated receptor potentially begins a signal-transduction cascade and recruits clathrin assembly proteins to it, creating a clathrin-coated pit. The coated pit is internalized and, because of the type and/or content of the assembly proteins, is directed to specific sorting endosomes that route the ligand to mitochondria and recycle or degrade the receptor. At the mitochondria, the ligand is transported by and unknown mechanism to the matrix or inner membrane, where it binds to OSCP, a portion of the F1/F0 ATPase-synthase. Binding of the ligand to OSCP inhibits the activity of the ATPase (Zheng \& Ramirez 1999a), essentially poisoning the electron transport chain. Elimination of oxidative phosphorylation causes some mitochondria to activate anaerobic respiration, leading to a change in mitochondrial morphology from the lamellar to the vesicular form (Idelman 1970, Shepard et al. 1998).

\section{Acknowledgements}

This work was supported by an NIH grant (MH5598603) to V D R.

\section{References}

Angermüller S, Künstle G \& Tiegs G 1998 Pre-apoptotic alteration in hepatocytes of $\mathrm{TNF} \alpha$-treated galactosamine-sensitized mice. Journal of Histochemistry and Cytochemistry 46 1175-1183.

Audy MC, Vacher P \& Dufy B 1996 17ß-Estradiol stimulates a rapid $\mathrm{Ca}^{2+}$ influx in LNCaP human prostate cancer cells. European Journal of Endocrinology 135 367-373.

Bradford MM 1976 A rapid and sensitive method for the quantitation of microgram quantities of protein utilizing the principle of protein-dye binding, Analytical Biochemistry 72 248-254.

Bression D, Michard M, Le Dafniet M, Pagesy P \& Peillon F 1986 Evidence for a specific estradiol binding site on rat pituitary membranes. Endocrinology 119 1048-1051.

Enmark E, Pelto-Huikko M, Grandien K, Lagercrantz S, Lagercrantz J, Fried G, Nordenskjold M, \& Gustafsson JA 1997 Human estrogen receptor beta-gene structure, chromosomal localization, and expression pattern. Journal of Clinical Endocrinology and Metabolism 82 4258-4265.

Garcia-Segura LM, Olmos G, Tranque P \& Naftolin F 1987 Rapid effects of gonadal steroids upon hypothalamic neuronal membrane ultrastructure. Journal of Steroid Biochemistry 27 615-623.

Geuze HJ, Slot JW \& Strous GJAM 1983 Intracellular site of asialo-glycoprotein receptor-ligand uncoupling: double-label immunoelectron microscopy during receptor-mediated endocytosis. Cell 32 277-287.

Gu Q, Korach KS \& Moss RL 1999 Rapid action of $17 \beta$-estradiol on kainate-induced currents in hippocampal neurons lacking intracellular estrogen receptors. Endocrinology 140 660-666. 
Idelman S 1970 The ultrastructure of the mammalian adrenal cortex International Review of Cytology 27 181-281.

Joe I, Zheng J \& Ramirez VD 1997 Progesterone-3-BSA and $17 \beta$-estradiol-6-BSA bind to glyceraldehyde-3-phosphate dehydrogenase (G3PD). Abstracts of the 27th Annual Meeting of the Society for Neuroscience, New Orleans, LA, USA, pp 712 (abstract).

Katzenellenbogen JA, O’Malley BW \& Katzenellenbogen BS 1996 Tripartite steroid receptor pharmacology: interaction with multiple effector sites as a basis for the cell- and promoter-specific action of these hormones. Molecular Endocrinology 10 119-131.

Lagrange AH, Ronnekleiv OK \& Kelley MJ 1997 Modulation of G-protein coupled receptors by an estrogen receptor that activates protein kinase A. Molecular Phamacology 51 605-612.

Marino M, Pallottini V \& Trentalance A 1998 Estrogens cause rapid activation of $\mathrm{IP}_{3}-\mathrm{PKC}-\alpha$ signal transduction pathway in HEPG2 cells. Biochemical and Biophysical Research Communications 245 254-258.

Massas R, Korenstein R \& Benayahu D 1998 Estrogen modulation of osteoblastic cell-to-cell communication. Journal of Cellular Biochemistry $69282-290$.

Mattick S, Glenn K, de Haan G \& Shapiro DJ 1997 Analysis of ligand dependence and hormone response element synergy in transcription by estrogen receptor. Journal of Steroid Biochemistry and Molecular Biology 60 285-294.

Migliaccio A, Di Domenico M, Castoria G, de Falco A, Bontempo P, Nola E \& Auricchio F 1996 Tyrosine kinase/p21 ras/MAP-kinase pathway activation by estradiol-receptor complex in MCF-7 cells. EMBO Journal 15 1292-1300.

Moats RK \& Ramirez VD 1998 Rapid uptake and binding of estradiol-17ß-6-(O-carboxymethyl)oxime: ${ }^{125}$ I-labeled BSA by female rat liver. Biology of Reproduction 58 531-538.

Moats RK \& Ramirez VD 1999 Direct visualization of membranemediated uptake and translocation of estrogen-BSA:colloidal gold by Hep G2 cells. Biology of Reproduction 60 (Suppl 1) 243.

Munson PJ \& Robard D 1980 LIGAND: a versatile computerized approach for characterization of ligand-binding systems. Analytical Biochemistry 107 220-239.

Norfleet AM, Tomas ML, Gametchu B \& Watson CS 1999 Estrogen receptor- $\alpha$ detected on the plasma membrane of aldehyde-fixed GH3/B6/F10 rat pituitary tumor cells by enzyme-linked immunocytochemistry. Endocrinology 140 3805-3814.

Pietras RJ \& Szego CM 1977 Specific binding sites for oestrogen at the outer surfaces of isolated endometrial cells. Nature 265 69-72.

Pietras RJ \& Szego CM 1979 Metabolic and proliferative responses to estrogen by hepatocytes selected for plasma membrane binding sites specific for estradiol-17ß. Journal of Cellular Physiology 98 145-160.

Prevot V, Croix D, Rialas CM, Poulain P, Fricchione GL, Stefano GB \& Beauvillain J-C 1999 Estradiol coupling to endothelial nitric oxide stimulates gonadotropin-releasing hormone release from rat median eminence via a membrane receptor. Endocrinology 140 652-659.

Ramirez VD 1996 How do steroids act? Lancet 347 630-631.

Ramirez VD \& Zheng J 1999 Non-genomic effects of estrogens. In Handbook of Experimental Pharmacology: Estrogens and Anti-estrogens, pp 171-200. Eds M Oettal \& E Schillinger. Heidelberg: Springer-Verlag.
Ramirez VD, Zheng J \& Siddique KM 1996 Membrane receptors for estrogen, progesterone, and testosterone in the rat brain: fantasy or reality. Cellular and Molecular Neurobiology 16 175-197.

Razandi M, Pedram A, Greene GL \& Levin ER 1999 Cell membrane and nuclear estrogen receptors (ERs) originate for a single transcript: studies of ER $\alpha$ and $\operatorname{ER} \beta$ expressed in Chinese hamster ovary cells. Molecular Endocrinology 13 307-319.

Rosner W 1991 Plasma steroid-binding proteins. Endocrinology and Metabolism Clinics of North America 20 697-720.

Schmid SL 1997 Clathrin-coated vesicle formation and protein sorting: an integrated process. Annual Review of Biochemistry 66 511-548.

Shepard TH, Muffley LA \& Smith LT 1998 Ultrastructural study of mitochondria and their cristae in embryonic rats and primate $(N$. nemistrina). Anatomical Record 252 383-392.

Sorkin A \& Carpenter G 1993 Interaction of activated EGF receptors with coated pit adaptins. Science 261 612-615.

Sorkina T, Bild A, Tebar F \& Sorkin A 1999 Clathrin, adaptors and eps15 in endosomes containing activated epidermal growth factor receptors. Journal of Cell Science 112 317-327.

Synnes M, Prydz K, Lovdal T, Brech A \& Berg T 1999 Fluid phase endocytosis and galactosyl receptor-mediated endocytosis employ different early endosomes. Biochimica et Biophysica Acta 1421 317-328.

Szego CM \& Pietras RJ 1981 Membrane recognition and effector sites in steroid hormone action. In Biochemical Actions of Hormones, vol 8, pp 308-463. Ed G Litwack. New York: Academic Press.

Troyan MB, Gilman VR \& Gay CV 1997 Mitochondrial membrane potential changes in osteoblasts treated with parathyroid hormone and estradiol. Experimental Cell Research 233 274-280.

Wehling M 1997 Specific, nongenomic actions of steroid hormones. Annual Review of Physiology 59 365-393.

Zheng J \& Ramirez VD 1997 Demonstration of membrane estrogen binding proteins in rat brain by ligand blotting using a $17 \beta$-estradiol- $\left[{ }^{125} \mathrm{I}\right]$ bovine serum albumin conjugate. Journal of Steroid Biochemistry and Molecular Biology 62 327-336.

Zheng J \& Ramirez VD 1999a Purification and identification of an estrogen binding protein from rat brain: oligomycin sensitivity-conferring protein (OSCP), a subunit of mitochondrial F0F1-ATP synthase/ATPase. Journal of Steroid Biochemistry and Molecular Biology 68 65-75.

Zheng J \& Ramirez VD 1999 b Rapid inhibition of rat brain mitochondrial proton F0F1-ATPase activity by estrogens: comparison with $\mathrm{Na}^{+}, \mathrm{K}^{+}$-ATPase of porcine cortex. European Journal of Pharmacology 368 95-102.

Zheng J, Ali A \& Ramirez VD 1996 Steroids conjugated to bovine serum albumin as tools to demonstrate specific steroid neuronal membrane binding sites. Journal of Psychiatry and Neuroscience 21 187-197.

Received 21 February 2000

Accepted 4 May 2000 